\title{
No Place Like Home: Anti-Vietnamese Discrimination and Nationality in Cambodia
}

\author{
Jennifer S. Berman $\dagger$
}

On the border between Cambodia and Vietnam, thousands of ethnic Vietnamese refugees live on boats, having fled their homes within Cambodia. A great many more ethnic Vietnamese still live in Cambodia, although their legal status there is precarious at best. Cambodia's legislature has failed to pass a nationality law to clarify the status of the ethnic Vietnamese, but has passed an immigration law that could be used to deport those ethnic Vietnamese living in Cambodia. Vietnam has been reluctant to accept the refugees from Cambodia, and many of the refugees themselves consider Cambodia, not Vietnam, to be their true home. In this Comment, the author argues that both national and international legal norms require the Cambodian legislature to pass a non-discriminatory nationality law similar to those in force in other Southeast Asian countries. Such a law would give most of the ethnic Vietnamese who have lived in Cambodia full Cambodian nationality. In so advocating, the author considers and rejects arguments that Cambodia has the right under international conventions to deport ethnic Vietnamese as a remedy for actions taken by the Vietnamese government. The author also demonstrates that a deportation scheme would face enormous logistical obstacles. Finally, the author sketches the basis for an acceptable, non-discriminatory nationality law.

\section{INTRODUCTION}

On July 1, 1994, representatives from the United Nations High Commissioner for Refugees (UNHCR), the World Food Program (WFP),

Copyright $(1) 1996$ California Law Review, Inc.

$\dagger$ Jennifer Berman, A.B. 1991, Brown University; J.D. 1996, Boalt Hall School of Law, University of Califomia, Berkeley. I would like to thank Professor Carolyn Patty Blum and Brad Adams for their help, guidance, and encouragement; Sum Sok Ry, for his skillful translation and dedication; the Townsend Center for the Humanities, whose grant made this project possible; Amnon Reichman, Allen Hicken, and Tom Ginsburg for their helpful remarks and criticism; Maria Shanle, Dena Graff, Chris Pederson, Sean Anderson, and all the other members of California Law Review whose thoughtful editing improved this piece. All remaining mistakes and omissions are my own. 
the World Health Org-usization (WHO), and several other human rights non-governmental organizations (NGOs) undertook the five-hour boat journey from Phnom Penh, Cambodia, ${ }^{1}$ to Chrey Thom, located on the Bassac River, on the border of Vietnam and Cambodia. ${ }^{2}$ The group went to investigate the living conditions of the 6,000 ethnic Vietnamese, alternatively called "boat people"3 or "internally displaced persons,"4 who were living on their boats at the border.

The human rights workers were alarmed and saddened by what they saw in Chrey Thom. Hunger had forced many of the ethnic Vietnamese families to sell their boats to pay for food; consequently, the remaining boats were dangerously overcrowded. Due to unsanitary living conditions, the health of the boat people had deteriorated. ${ }^{6}$ Many suffered from diarrhea, ${ }^{7}$ while others died from malaria because they had no money to buy medicine. ${ }^{8}$

Malnutrition remained a constant problem because food was scarce. Because the boat people were denied permission to fish or farm, their food consisted solely of the monthly rations of rice and fish paste provided by the World Food Program.' Cooking this food presented another challenge for the boat people because they were not allowed off their boats to collect firewood unless they bribed the ethnic Khmers living nearby. Most had long ago run out of money to do so.

Children on the boats particularly suffered. One-third of the children suffered from severe malnutrition, ${ }^{10}$ which, coupled with lack of exercise, caused their bodies to be underdeveloped. The children received no education because they were not allowed to go to school in

1. 1 have decided to use "Cambodia" rather than "Kampuchea"; for a discussion about the difference between the names "Cambodia" and "Kampuchea," see THE CAMBODIAN AgONY xiv (David A. Ablin \& Marlowe Hood eds., 2d ed. 1990).

2. During the summer of 1994, I was an intern with the legal advisor to the National Assembly Commission on Human Rights in Cambodia. For this reason, I was able to accompany the UNHCR on this trip.

3. E.g., Boat-people Stranded on the Cambodian-Vietnamese Border, UNHCR Press Release (Mar. 30, 1994) (on file with author) [hereinafter UNHCR Press Release].

4. E.g., Michael Kirby, U.N. Special Representative to Cambodia, Speech at the U.N. Center for Human Rights in Cambodia (July 1994).

5. Mark Dodd, Plight of 5,000 Stranded Ethnic Vietnamese Worsens, Reuters World Scrvice, Jan. 8, 1994, available in LEXIS, World Library, Reuter World Service File.

6. For example, the polluted river water served as bathtub, toilet, playground, and food source. William Branigin, Vietnam's New 'Boat People': Fleeing Persecution in Cambodia, Many Return to Their Homeland, WASH. Post, May 8, I993, at Al5.

7. Leo Dobbs, U.N. Tries to Help Vietnamese Stranded at Cambodian Border Outpost, Deutsche Presse-Agentur, July 29, 1994, available in LEX1S, World Library, Deutsche Press File.

8. Dodd, supra note 5.

9. Sue Downie, Stranded Vietnamese to Receive UN Assistance, UP1, Aug. 12, 1993, available in LEXIS, Topnws Library, UPI File.

10. Id. 
Cambodia, and their parents could no longer afford the tuition for education in Vietnam."

The boat people had been trapped at the border for almost two years. Most had been among the over 20,000 ethnic Vietnamese who fled racially motivated massacres of ethnic Vietnamese in Cambodia in 1992 and 1993.12 As a result of these massacres, the United Nations Transitional Authority in Cambodia (UNTAC), which was responsible for maintaining peace within Cambodia, felt it could no longer guarantee the safety of the ethnic Vietnamese in Cambodia. ${ }^{13}$ Thousands of ethnic Vietnamese fled to the border in fear for their lives. Because the ethnic Vietnamese were further victimized en route by banditry and extortion, ${ }^{14}$ UNTAC agreed to escort them down the river to the border with land and plane patrols. ${ }^{15}$

At the time of these flights, both UNTAC and the ethnic Vietnamese themselves believed that the ethnic Vietnamese would be allowed to return to their homes at will; many of the ethnic Vietnamese state that they would have preferred to risk staying in Cambodia otherwise. ${ }^{16}$ However, when the boat people attempted to return home to Cambodia after the UNTAC-supervised elections in 1993, the Cambodian border police stated that they would not let the boat people re-enter until the National Assembly passed a bill explicitly providing them with Cambodian nationality. ${ }^{17}$ To date, no such bill has been passed.

11. Dobbs, supra note 7.

12. Ben Kieman, The Inclusion of the Khmer Rouge in the Cambodian Peace Process: Causes and Consequences, in Genocide and Democracy in Cambodia: THE Khmer Rouge, the UNITEd Nations AND the InTERnational Community 191, 243-44 (Ben Kieman ed., 1993). It is believed that many of the others who fled Cambodia remain in Vietnam, but no one knows for certain.

13. The mandate of UNTAC caused some confusion regarding whether the U.N. was to create or merely to maintain peace in Cambodia. The U.N. insisted that it was there to maintain peace, and that the Cambodian government itself was responsible for protecting the Vietnamese in Cambodia. Mark Dodd, UN to Protect Vietnamese in Cambodia, Reuter Library Report, Mar. 31, 1993, available in LEXIS, World Library, Reuter World Service File; Mark Dodd, UN Says It Cannot Protect Fleeing Vietnamese, Reuter Library Report, Mar. 26, 1993, available in LEXIS, World Library, Reuter World Service File.

It is unclear whether UNTAC could not protect the Vietnamese because of lack of resources or lack of will. Compare id. (quoting a U.N. peacekeeper as saying that "[t]here is no lack of resources ... just a lack of will") with UN in Cambodia Says Help Scarce for Vietnamese, Reuter Library Report, Apr. 5, 1993, available in LEXIS, World Library, Reuter World Service File (quoting the head of UNTAC as saying that "UNTAC would do what it can within its mandate, with its limited resources").

14. All Things Considered: Khmer Rouge Wants Vietnamese Out of Cambodia (National Public Radio broadcast, Apr. 29, 1993).

15. Dodd, U.N. to Protect Vietnamese in Cambodia, supra note 13.

16. Downie, supra note 9.

17. See UNHCR Press Release, supra note 3; see also Dobbs, supra note 7.

Nationality is a legal term of art that denotes the juridical and political connection between an individual and the state; the individual and state hold reciprocal rights and duties due to this connection. In particular, the state provides intemational protection on behalf of its nationals. PARRY 
Just as the Cambodian government refuses to allow the boat people to return, the Vietnamese government has discouraged them from resettling in Vietnam. The Vietnamese government considers the boat people to be Cambodian nationals, for whom the Cambodian government should be responsible. ${ }^{18}$ The Vietnamese government fears that allowing the boat people to cross the border would exacerbate unemployment and overpopulation in Vietnam. ${ }^{19}$ In fact, the boat people who entered Vietnam did face additional troubles such as housing shortages ${ }^{20}$ and unemployment. ${ }^{21}$ Vietnam set up border centers to aid the boat people, and continued to request U.N. intervention and assistance, with little success. ${ }^{22}$

and Grant Encyclopaedic Dictionary of International Law 249 (Clive Parry et al. eds., 1986); The Movement of Persons Across Borders 39 (Louis B. Sohn \& Thomas Buergenthal eds., 1992). While citizenship may also denote this connection, citizenship mainly applies to republican forms of government. Because Cambodia has a constitutional monarchy, nationality is the more appropriate term here. See PARRY AND GRANT, supra, at 60 .

If the ethnic Vietnamese were to be deported as non-nationals after the passage of the law, the Cambodian government felt it would be more expedient to forbid their re-entry into Cambodia preemptively. Some ethnic Vietnamese were able to cross the border by land, after selling their boats and bribing border guards to permit their passage. Most of the boat people, however, did not have enough money to offer such bribes. See Dodd, supra note 5; U.S. DEP'T OF STATE, Country Reports on Human Rights Practices for 1994, at 554 (I995) (report to Senate Comm. on Foreign Relations and House Comm. on International Relations) [hereinafter 1994 HUMAN RighTs REPORT]. Ironically, many of these same people had to bribe their way out of Cambodia as well. John Rogers, Cambodian Refugee Exodus Confronts Vietnam, Reuter Library Report, Apr. 9, 1993, available in LEXIS, World Library, Reuter World Service File.

18. Som Sattana, Vietnamese Fleeing Cambodia after Khmer Rouge Threats, UP1, Apr. 4, 1993, available in LEXIS, World Library, UPI File. Under Vietnamese law, a person is a Vietnamese national if he or she was bom in Vietnam or has been naturalized Vietnamese. One can also be a Vietnamese national if one is born outside Vietnam and: 1) both parents are Vietnamese; or 2) one parent is Vietnamese, and the other is stateless or of unknown nationality; or 3) one parent is Vietnamese, the other is of a different nationality, and the parents choose for the child to be a Vietnamese national. However, under Article 9 of the Vietnamese nationality code, Vietnamese nationals can renounce their Vietnamese nationality. See Socialist Republic of Vietnam: Law on Vietnamese Nationality, 1988, I5 REv. SocIALIST L. 287, 287-93 (1989). Thus, without considering the specifics of each ethnic Vietnamese person in Cambodia or at the border, those claiming to be Cambodian have, most likely, effectively renounced their Vietnamese nationality according to the Vietnamese government, which is unwilling to accept them as nationals. Because neither country is willing to accept the ethnic Vietnamese living in Cambodia as nationals, many people may be left stateless, which is a disfavored result under international documents such as the Convention on the Reduction of Statelessness, Aug. 30, 1961, 989 U.N.T.S. 175.

19. Branigin, supra note 6 .

20. While the Vietnamese government tried to integrate these people into villages rather than establish refugee camps, these refugees required governmental assistance for food and housing. The U.N. did not provide money for this project. Reese Erlich, Refugees From Cambodia Strain Vietnam's Resources, CHristian SCI. MonitoR, July 28, 1993, at 3.

21. In Cambodia, many ethnic Vietnamese fish in the Cambodian lake of Tonle Sap, one of the richest fishing lakes in the world. Sonya Hepinstall, Fleeing Vietnamese Hurt Cambodian Economy, Reuter Library Report, May 6, 1993, available in LEXIS, Topnws Library, Reuter Library Rptort File. While an economic niche existed for the ethnic Vietnamese in Cambodia as fisherman, this niche did not exist in Vietnam. See Branigin, supra note 6.

22. Rogers, supra note 17. 
Just as Vietnam hesitates to absorb them, most boat people are not eager to live in Vietnam. Few boat people have family ties or connections there. ${ }^{23}$ Most speak fluent Khmer and consider themselves Cambodian. ${ }^{24}$ In fact, many have documentation establishing ties to Cambodia for years, some even for generations. ${ }^{25}$ The only factor tying many of these people to Vietnam is their ethnicity.

Nevertheless, because of the lack of a nationality law, these longterm residents of Cambodia cannot establish their right to remain in Cambodia. Government officials in Phnom Penh and at the border exploit this legal vacuum to justify their refusal to allow the boat people back into Cambodia. ${ }^{26}$ Thus, thousands of boat people remain trapped at the border, with the hope that Cambodia will allow their return as soon as a Cambodian nationality law passes. ${ }^{27}$

The sad irony is that any law approved by the Cambodian National Assembly would be unlikely to grant Cambodian nationality to the ethnic Vietnamese. ${ }^{28}$ The Cambodian National Assembly passed an immigration law on August 26, 1994. ${ }^{29}$ The law provides extensive guidelines and authorization for fining, incarcerating, and deporting non-Cambodian resident aliens without due process. ${ }^{30}$ However, there is no definition of Cambodian nationality in this law, or anywhere else in Cambodian law.

Many other countries generally have constitutions or immigration laws that include nationality clauses delineating to whom various immigration provisions apply. ${ }^{31}$ However, human rights lawyers working in

23. Hepinstall, supra note 21.

24. See UNHCR Press Release, supra note 3.

25. Id. Also, many of these people have Cambodian identity cards, which UNTAC chief Yasushi Akashi noted should grant them the right to re-enter Cambodia. Bala Chandran, Cambodia: Displaced Vietnamese Families Remain Homeless, Inter Press Service, Aug. 17, 1993, available in LEXIS, World Library, Inter Press Service File.

26. In 1993, government officials also recommended that the ethnic Vietnamese remain outside Cambodia because of the continuing Khmer Rouge threat. Chandran, supra note 25 . Most human rights workers considered this response by the government to be disingenuous.

27. Rogers, supra note 17.

28. Ethnic Khmers make up the majority of those living in Cambodia. In 1962, Khmers comprised $80 \%$ of the population; in 1981, Khmers comprised $90 \%$ or more of the population. Robert $\mathrm{K}$. Headley, Jr., The Society and Its Environment, in CAMbodia: A CounTRY STUdY 83 (Russell R. Ross ed., 3d ed. 1990). In addition to the ethnic Vietnamese, other ethnic minorities in Cambodia include the Muslim Cham and the Chinese. Id. Because the situation facing the ethnic Vietnamese is complex, discussion of the immigration law's impact on other ethnic minorities is necessarily outside the scope of this paper.

29. Cambodia Passes Controversial Immigration Law, Reuters World Service, Aug. 26, I994, available in LEXIS, World Library, Reuter World Serviee Library. Only one Member of Parliament-an ethnic Cham named Ahmad Yahaya-voted against this law. He voted against the law because of its potcntial to enable serious human rights abuses. Id.

30. Cambodian Law on Immigration, arts. 29-30 (1994).

31. The Movement of Persons Across Borders, supra note 17, at 42 . Briefly stated, there are two basic ways in which nationality is granted. One way confers nationality based on jus soli, or 
Cambodia believe that a main reason why the National Assembly did not include a nationality clause was because it did not want to grant Cambodian nationality to ethnic Vietnamese..$^{32}$ Ethnicity-based discrimination against the Vietnamese, however, is incompatible with several international human rights norms. Specifically, Cambodia has ratified a number of international conventions addressing racial discrimination, including the International Convention on the Elimination of All Forms of Racial Discrimination. ${ }^{33}$ This Convention forbids discrimination based on ethnicity. ${ }^{34}$

The Cambodian legislature was caught between the proverbial rock and hard place. The Cambodian government did not want to alienate the international community, on whom it depends for aid, by blatantly violating international agreements. Nor does it want to face the ramifications of offending Vietnam, its traditional adversary, by overtly discriminating against the ethnic Vietnamese. ${ }^{35}$ Yet the government did not want to grant Cambodian nationality to the ethnic Vietnamese. The legislature attempted to avoid this predicament by not passing any nationality law at all. While human rights advocates working in Cambodia found this approach less than ideal, it seemed preferable to an overtly discriminatory nationality law. ${ }^{36}$

However, human rights workers now fear that the Cambodian immigration law, though devoid of nationality provisions, will be used as a weapon against the ethnic Vietnamese in Cambodia, who currently face ethnicity-based harassment, discrimination, and exploitation. ${ }^{37}$ Because there is no nationality law granting the ethnic Vietnamese rights, they face persecution with little legal clarification, protection, or recourse.

This persecution is not limited to the ethnic Vietnamese like the boat people, who have fled Cambodia. Human rights workers suspect that the immigration law constitutes the first step toward an affirmative, officially sponsored program to deport all ethnic Vietnamese from

right of the land: people bom in the territory would qualify for nationality. The second way of granting nationality accords nationality based upon jus sanguinis, or right of descent: if historically one's ancestors were from that country, one would qualify for nationality. Additionally, people who have lived in the territory for a certain period of time may be allowed to gain nationality through naturalization. See generally RichaRd Plender, INTERnAtional MigRation LAW 9-48 (rev. 2d ed. 1988).

32. Interviews with anonymous human rights lawyers in Phnom Penh (July-Aug. 1994).

33. Opened for signature Mar. 7, 1966, 660 U.N.T.S. 195.

34. Id. arts. 1, 5, 660 U.N.T.S. at 216, 220-22.

35. For a discussion of the historical roots of the animosity between Cambodia and Vietnam, see infra Part I.

36. Interviews with human rights lawyers in Phnom Penh (July-Aug. I994).

37. See, e.g., Leah Makabenta, Cambodia: Only for Khmers?, Inter Press Service, Aug. 25, 1994, available in LEXIS, World Library, Inter Press Service File. 
Cambodia en masse. ${ }^{38}$ Representatives from the Cambodian Ministry of the Interior have repeatedly approached the UNHCR to request assistance in establishing deportation centers. ${ }^{39}$ The Ministry of the Interior expressed the hope that with international assistance, all ethnic Vietnamese living in Cambodia could be rounded up, interned, and deported en masse to Vietnam. ${ }^{40}$ This plan ignores the fact that many of these people were born in Cambodia, speak Khmer, and have no ties to Vietnam other than their ethnicity.

Further, the minister of the interior has recently instructed provincial government workers and police to register and report all "illegal aliens," and to expel them within ten days of their discovery. ${ }^{41}$ The official directive defines illegal aliens to be those people within Cambodia who hold fraudulent documents or no documents at all. Anyone who has a Cambodian ID card but "cannot speak Khmer" is presumed to hold a fraudulent document, ${ }^{42}$ but the directive does not establish a test to determine whether someone can "speak Khmer." Because Khmers often criticize ethnic Vietnamese for being "unable to speak Khmer" due to their Vietnamese accents, one can surmise that this directive may be intended to ensure the expulsion of ethnic Vietnamese.

The Cambodian government probably does not have adequate resources to fully implement a mass deportation scheme at this time. ${ }^{43}$ Nevertheless, many ethnic Vietnamese could still be driven out of Cambodia unjustly. Under the directive, government officials are authorized to expel individuals ad hoc, without due process or legal safeguards, so it is likely that the demand for bribes to avoid such deportation will increase. ${ }^{44}$ Ultimately, many ethnic Vietnamese will be forced to leave as

38. See Leo Dobbs, Cambodian Immigration Law is Bad News for Vietnamese, Deutsche PresseAgentur, Sept. 11, 1994, available in LEX1S, World Library, Deutsche Presse File (quoting the United Nations High Commissioner for Refugees Representative in Cambodia, Serge Ducasse, as saying that the law could be used for ethnic cleansing and mass deportation of non-Khmers); Cambodian Immigration Law Under Fire, UPI, Aug. 16, 1994, available in LEXIS, Topnws Library, UPI File (quoting anonymous human rights workers as sources).

39. Dobbs, supra note 38; Makabenta, supra note 37; Human Rights Group Warns of Possible New Abuses in Cambodia, Agence France Presse, Aug. 16, 1994, available in LEXIS, World Library, Agence France Presse File.

40. Serge Ducasse, Speech at the Foreign Correspondents Club, Phnom Penh (Aug. 3, 1994).

41. Ministry of Interior, Measures for Implementing the Planning [sic] No. 017 PL (June 8, 1995) (on file with author). This directive was accidentally leaked to human rights workers in Cambodia.

42. Ministry of Interior, Circular Letter No. 005 (July 11, I995) (on file with author).

43. A plan exists to establish a "camp" for illegal aliens near Sihanoukville, a city in southern Cambodia. However, the Cambodian government does not have the means to set up detention centers throughout the provinces, and would require the assistance of international NGOs for supplies. Robin McDowell \& Ek Madra. Sihanoukville Plans “Camp" for Illegal Aliens, Cambodia Dally, Aug. 1, 1995.

44. See Dobbs, supra note 38 (citing one U.N. source as saying that flow charts exist at the Ministry of Interior to determine which officials are entitled to what percentage of bribe proceeds). 
bribery expenses become prohibitive. In short, vast discretion inherent in the law and the consequent demand for bribery may concomitantly allow the government to achieve its goal of deportation semicovertly. The government could avoid passing an overtly discriminatory law, which would offend international benefactors, and still leave the ethnic Vietnamese in Cambodia vulnerable to persecution.

This Comment argues that the Cambodian National Assembly must pass a non-discriminatory nationality law in order to protect the human rights of all people in Cambodia and to comply with international and Cambodian legal obligations. Part I provides the historical context in which to consider nationality and the ethnic Vietnamese in Cambodia. It describes how centuries of border skirmishes, land disputes and annexation, and racial discrimination have led to the current animosity many Khmers feel toward the ethnic Vietnamese.

Part II argues that Cambodia should pass a non-discriminatory law for legal and policy reasons. This Part addresses the international and domestic legal commitments with which a Cambodian nationality law must comply. These documents include the Paris Peace Accords, ${ }^{45}$ the Cambodian Constitution, and international conventions such as the Convention on the Elimination of All Forms of Racial Discrimination. ${ }^{46}$ This Part also analyzes Cambodia's rights under the 1949 Geneva Convention Relative to the Protection of Civilian Persons in Times of $\mathrm{War}^{47}$ because some Cainbodian politicians argue that the ethnic Vietnamese in Cambodia could be deported legally due to Vietnam's violation of this Convention. This Part explores whether such a violation occurred, and argues that even if Vietnam did violate this Convention, deportation of ethnic Vietnamese civilians would constitute an inappropriate remedy. In addition, this Part addresses why it would be in Cambodia's own selfinterest to pass a non-discriminatory law and discusses how evidentiary problems may hinder the implementation of any proposed law.

Part III suggests an approach to Cambodian nationality that is compatible with Cambodia's legal obligations. This Part argues that Cambodia should pass a non-discriminatory nationality law that combines aspects of jus soli and jus sanguinis, and looks to the nationality laws of other Southeast Asian nations to explore what a Cambodian nationality law should include. This Part also argues that Cambodian immigration and nationality law should incorporate due process

45. Agreements Elaborating the Framework for a Comprehensive Political Settlement of the Cambodian Conflict, Oct. 23, 1991, 31 I.L.M. 174 [hereinafter "Paris Peace Accords" or "Accords"].

46. Supra note 33.

47. Geneva Convention Relative to the Protection of Civilian Persons in Time of War, Aug. 12, 1949, 6 U.S.T. 35I6, 75 U.N.T.S. 287 [hereinafter Geneva Convention]. 
safeguards and reduce official discretion, which in the past has allowed for discrimination against the ethnic Vietnamese.

HISTORICAL BACKGROUND

\section{A. Territorial Conquest, Political Subjugation, and Racial Arimosity in Cambodia}

One can understand, although not justify, the Cambodian goal of mass deportation of ethnic Vietnamese by examining the racist attitudes many Khmers, including some members of the Cambodian government, ${ }^{48}$ hold toward the Vietnamese. ${ }^{49} \mathrm{~A}$ speech at the Paris Peace Conferences by Norodom Sihanouk, the current king of Cambodia, exemplifies the hostility and suspicion that is commonplace. ${ }^{50}$ Participants at the Conference called for the withdrawal of all Vietnamese troops from Cambodia. ${ }^{51}$ Sihanouk, however, claimed that the withdrawal of Vietnamese troops alone would be insufficient, because some Vietnamese soldiers would be able to remain in disguise. He thus advocated the peaceful repatriation of all ethnic Vietnamese, with the help of the International Committee of the Red Cross (ICRC) and the UNHCR. ${ }^{52}$

48. Members of Parliament and the general public share this anti-Vietnamese sentiment. Sihanouk Seeks to Allay UN Chief's Fears over Ethnic Vietnamese, Agence France Presse, Sept. 18, 1994, available in LEXIS, World Library, Agence France Presse File. This racism is exhibited, for example, by the use of the word "yuon," or savage, to refer to the Vietnamese during parliamentary debates regarding the immigration law. Use of this term provoked specific complaint from the Vietnamese press. Anh Asks Sihanouk to Protect Vietnamese in Cambodia, Agence France Presse, Aug. 29, 1994, available in LEXIS, World Library, Agence France Presse File.

49. There is some debate whether persecution of the ethnic Vietnamese constitutes racism or ethnicity-based discrimination. Most scholars of Cambodian history use the terms race and ethnicity interchangeably. Technically, race is a social construction that defines people as members of groups with different traits and may encompass notions of hierarchy and power. JEFF SPINNER, THE BOUNDARIES OF CITIZENSHIP 19-25 (1994). Ethnic groups base their ethnic identity on a sense of shared cultural attributes and group origins; ethnicity is not externally imposed, and people of different ethnic groups can downplay ethnicity via assimilation. Id. at 25-27.

Khmers are quite explicit that they consider the Vietnamese to be of a different race, as they use the Khmer word for race and not ethnicity when they describe the differences between the "Khmer race" and the "Vietnamese race". See id. at 16-17. Based on this information and the definitions described above, I will also use the term racism to describe the hostility toward the ethnic Vietnamese in Cambodia.

Finally, one may wonder how ethnic Vietnamese are distinguishable in Cambodia. Apparently, their "lighter skin color and finer features make them instantly recognizable to a Cambodian." Terry McCarthy, Vietnamese Flee Khmer Rouge "Cleansing", OtTawa Citizen, Apr. 2, 1993, at A8, available in WESTLAW, Otwctzn File, 1993 WL 6833714.

50. For a discussion of the Paris Peace Conferences, see infra text accompanying notes 182-84.

51. Vietnam ended Khmer Rouge domination of Cambodia when it invaded Cambodia in 1979; Vietnamese troops remained in Cambodia for approximately the next ten years. See infra Parts I.G \& 1.H.

52. Norodom Sihanouk, Speech to the Paris Peace Conference, July 30, 1989, in CambodiaThe 1989 Paris Peace Conference: Background Analysis and Documents 4 (Amitav Acharya et al. eds., 1991). 
Many members of the National Assembly agree with Sihanouk regarding the need for and desirability of wide-scale repatriation. For example, members of Parliament have argued that Cambodia should not grant nationality to the ethnic Vietnamese because this would help Vietnam in its ongoing scheme to colonize Cambodia. These arguments quickly turn into anti-Vietnamese diatribes that greatly exaggerate the number of ethnic Vietnamese living in Cambodia and the threat they pose to the country. ${ }^{53}$ One scenario postulates that every ethnic Vietnamese person in Cambodia, from the noodle seller to the construction worker to the sex worker, is actually a spy sent by the Vietnamese government to infiltrate Cambodian society. According to this theory, all spies allegedly are awaiting a signal from Hanoi, at which point they will arise en masse to colonize Cambodia. ${ }^{54}$

Although this conspiracy theory may seem paranoid, Khmer fear of the Vietnamese has some historical basis. Cambodia and Vietnam have been rivals for centuries, leading to national resentment, apprehension, and forcefully negative stereotypes..$^{55}$ The border of Vietnam and Cambodia has been the scene of more battles than nearly any other border in Asia. ${ }^{56}$ For centuries, Vietnam has periodically invaded, conquered, and annexed land from Cambodia. ${ }^{57}$ These territorial conquests and periods of political subjugation have resulted in a long history of Khmer animosity toward the Vietnamese ${ }^{58}$ to which all Cambodian regimes since 1954 have contributed (with the exception of the Vietnamese-backed People's Republic of Kampuchea, or PRK)..$^{59}$

The consequent Khmer racism directed toward the Vietnamese is both deeply felt and commonplace. Human Rights Watch-Asia, a respected human rights watchdog group, has described the hatred felt by many Khmers toward the ethnic Vietnamese as "almost pathological." 60

53. Interviews with Members of Parliament in Phnom Penh (June-Aug. 1994).

54. The Khmer Rouge similarly theorizes that all ethnic Vietnamese in Cambodia are soldiers in disguise. However, the Khmer Rouge, not satisfied by mere deportation, hopes to eliminate (i.e., kill) all these ethnic Vietnamese "soldiers" in Cambodia. Moreover, this plan also advocates mass slaughter of all ethnic Vietnamese women and children, because women bear children, and children grow up to be soldiers. Cambodia: Human Rights Before and After the Elections, Ası Watch, May 1993, at 20.

55. Elizabeth Becker, When The WAR WAS Over 335 (1986). For example, in Cambodian folklore, Vietnamese people serve as the ogres. McCarthy, supra note 49.

56. BECKER, supra note 55, at 337.

57. See id. at 340-42. The most recent invasion occurred in late 1978, when a Vietnamese invasion led to the overthrow of the Khmer Rouge regime. See infra Part I.G.

58. Cambodia: Human Rights Before and After the Elections, supra note 54, at 20; see NAYAN Chanda, Brother ENEMY: THE WAR AFTER ThE WAR S2 (1986).

59. David P. Chandler, A History of Cambodia 95 (1983). Moreover, this loss of territory has provoked government complaints from every Cambodian regime from 1848 up to the present (again excluding the PRK). Chanda, supra note 58, at 56.

60. Cambodia: Human Rights Before and After the Elections, supra note 54, at 20. 
Beginning in elementary school, Khmer children are taught to resent the loss of territory to Vietnam, and to fear the continuing threat that Vietnamese expansion poses to Cambodia. ${ }^{61}$ Cambodian popular culture also foments such resentment. Several Cambodian newspapers perpetuate anti-Vietnamese views and incite racial hatred with "rabidly antiVietnamese cartoons." 62

This racial hatred is palpable to many foreigners who have spent time in Cambodia. ${ }^{63}$ It unites numerous Khmers, cutting across age, education, and class lines, and includes taxi-drivers, servants, and Members of Parliament. This racism has repercussions for Khmers who are empathetic to the Vietnamese. At least one Khmer human rights worker has received death threats because of his work helping the ethnic Vietnamese. ${ }^{64}$ However, the ethnic Vietnamese themselves have been the primary victims of anti-Vietnamese animosity and agitation.

The following sections will describe how historic tensions between the Vietnamese and Khmer people have evolved and contributed to the current situation.

\section{B. Pre-Colonial Era (1620-1863)}

Vietnam began settling villages in Cambodian territory throughout the Mekong Delta in the 1620 s, and had completely annexed the region by the end of the next century ${ }^{65}$ The Mekong Delta region, a fertile area with excellent soil and an extensive coastline, had comprised a large part of Cambodia's territory and was Cambodia's only direct access to the South China Sea. ${ }^{66}$ Refusing to give up their historic claim to this region, many Cambodians still refer to this area as Kampuchea Krom, or lower Cambodia. ${ }^{67}$ The need to regain this territory has been a theme running through the ideology of many Cambodian regimes. ${ }^{68}$

61. Moming Edition: Khmer Rouge Killing Ethnic Vietnamese in Cambodia (National Public Radio broadcast, Mar. 26, 1993).

62. Tom Fawthrop, Cambodia: Will Immigration Law Lead to Mass Expulsion?, Inter Press Service, Oct. 19, 1994, available in LEXIS, World Library, Inter Press Service File.

63. Chanda, supra note 58, at 54. One journalist describes how foreign visitors have remarked upon Cambodian xenophobia and paranoia, which she calls pervasive and almost irrational when directed at the Vietnamese. She further explains how Cambodians blame Vietnam for everything from environmental damage to AIDS to the Khmer Rouge; some Cambodians even claim that Pol Pot was a Vietnamese agent sent to annihilate the Khmer race. Makabenta, supra note 37.

64. Interviews with anonymous human rights workers in Phnom Penh (July 1994).

65. See Chanda, supra note 58, at 51; see also Chandler, supra note 59, at 94; GARY KLINTworth, Vietnam's Intervention in Cambodia in International Law 2 (1989). The Vietnamese justified this expansion by referring to alleged Khmer mistreatment of Vietnamese settlers in this region. Donald M. Seekins, Historical Setting, in Cambodia: A Country Study, supra note 28 . at 1,15 .

66. ChANDLER, supra note 59 , at 94-95.

67. See, e.g., BECKER, supra note 55, at 141; CHANDA, supra note 58, at 56 . Along with the loss of territory, Cambodia lost a large portion of its population. These people face discrimination from the Vietnamese population as they continue to identify themselves as Khmer and speak the Khmer 
This period of annexation and colonization extended through the mid-1800s. ${ }^{69}$ The fear and resentment that developed among Khmers during this period led to Cambodian uprisings against and massacres of the Vietnamese in the 1840s, during which some Khmers boasted that they were "happy killing Vietnamese." suppressed these uprisings, thereby exacerbating Khmer animosity."

\section{French Protectorate (1863-1954)}

By the time the French arrived in 1863, Cambodia and Vietnam were already well-established adversaries. ${ }^{72}$ The arrival of the French was both a blessing and a burden for Cambodia. On the one hand, the French may have kept Vietnam from swallowing Cambodia entirely. ${ }^{73}$ On the other hand, the French, motivated by administrative convenience, drew new territorial boundaries that resulted in Cambodia's loss of additional land. ${ }^{74}$

In general, the French treated the Vietnamese better than they treated the Khmers. ${ }^{75}$ Many French administrators considered Vietnam to be the jewel of their colonial empire because the soil was fertile and the people were industrious. ${ }^{76}$ On the other hand, many French considered the Cambodians to be relatively lazy and incompetent. ${ }^{n}$ The French thus viewed the Vietnamese as the proper future rulers of Cam-

language, maintaining their own insulated culture despite the fact that Vietnam now governs their territory. Personal interviews with former Khmer residents of Kampuchea Krom, Phnom Penh (July 1994). However, the population of Kampuchea Krom has been overwhelmingly Vietnamese for centuries. Irwin Silber, KAMpuchea: The Revolution Rescued 46 (1986).

68. See, e.g., BECKER, supra note 55, at 141; ChANDA, supra note 58, at 56 . This area also includes Saigon, or Ho Chih Minh City, so it is unlikely that Vietnam will ever willingly surrender this territory to Cambodia.

69. The annexation was halted by the French Protectorate, established over Indochina in 1863. See infra Part I.C. Some twenty years before this period, Vietnam forcefully attempted to impose its own culture upon Cambodia, which sparked resentment. Chanda, supra note 58, at 51-52. This resentment was exacerbated by the huge cultural gap between Cambodia and Vietnam. Cambodian culture exhibits more Indian influence, whereas Vietnam exhibits more Chinese influence. Headley, supra note 28, at 110. This cultural difference was later exploited for nationalist aims by Lon Nol and Pol Pot. Chandler, supra note 59, at 127.

70. Chandler, supra note 59, at 130-33; Chanda, supra note 58, at 52.

71. See ChANDLER, supra note 59, at 130-32. The viciousness of the suppression appears in anti-Vietnamese folklore. One classic story that reemerged under the Khmer Rouge described how the Vietnamese buried three Khmers up to their necks and placed boiling tea kettles on their heads. Chanda, supra note 58 , at 52 .

72. See CHANDLER, supra note 59, at 136.

73. CAMBodia: A Country STUDY, supra note 28, at xxvii.

74. Chanda, supra note 58, at 54. For example, in 1949 the French agreed to the creation of a unified Vietnam that included the Kampuchea Krom area. KLINTwORTH, supra note 65, at 3.

75. See Chanda, supra note 58 , at 56.

76. BECKER, supra note 55 , at 52.

77. Id. 
bodia, ${ }^{78}$ recruited Vietnamese as civil servants to administer Cambodia, and generally gave the Vietnamese higher positions than the Khmers. ${ }^{79}$ This behavior provoked complaints of favoritism and exacerbated Khmer anxiety. ${ }^{80}$ The consequent fear of Vietnamese conquest led to a convergence of Cambodian nationalism and government-encouraged antipathy toward the Vietnamese,$^{81}$ which is described in the next Sections.

D. Independence and the First Sihanouk Regime (1954-1970)

Although Vietnam, Laos, and Cambodia purportedly joined together to oust the French from Southeast Asia, it was Vietnam that dictated how and when to organize against the French. Cambodian needs were subordinated to those of Vietnam. ${ }^{82}$ The 1954 Geneva Accords mandated the terms for the decolonization of Indochina. ${ }^{83}$ Nevertheless, Cambodian leader Prince Norodom Sihanouk remained anxious due to the ever-present threat of Vietnamese expansion into Cambodia ${ }^{84}$

By constantly protesting prior territorial loss to Vietnam, Sihanouk was able to rouse greater antipathy against the ethnic Vietnamese. ${ }^{85}$ For example. during the 1960s, Sihanouk fused his nationalist rhetoric with ethnic slurs against the Vietnamese. ${ }^{86} \mathrm{He}$ employed a nationalist credo that expressed a supposedly desperate need to preserve the Khmer race. ${ }^{87}$ By making incendiary statements such as, "no Annamite (Vietnamese) will sleep peacefully until he has succeeded in pushing Cambodia towards annihilation, having made it first go through the stage of slavery," 88 Sihanouk tried to manipulate fear of Cambodia's hereditary enemy to serve his political agenda of stirring nationalist sentiment. ${ }^{89}$

78. Id. at 343 .

79. Seekins, supra note 65 , at 18,21 .

80. Id. at 20-21.

81. See Chandler, supra note 59, at 172.

82. BECKER, supra note 55 , at 88 .

83. Agreement on the Cessation of Hostilities in Cambodia, July 20, 1954, Cambodia-Vietnam, reprinted in Robert F. Randle, Geneva 1954: The Settlement of the Indochinese War 572 (1969).

84. BECKER, supra note 55 , at 97 .

85. CHANDA, supra note 58 , at 54,56 .

86. CHANDLER, supra note 59 , at 184.

87. Serge Thion, The Pattern of Cambodian Politics, in The Cambodian Agony, supra note 1 , at $149,156$.

88. KLINTwORTH, supra note 65 , at 3 .

89. Thion, supra note 87 , at 156 . 


\section{E. Lon Nol (1970-1975)}

Sihanouk ruled Cambodia until 1970, when General Lon Nol, Sihanouk's former prime minister, gained control of Cambodia through a coup d'état. A fervent anti-communist and an ally of the United States against North Vietnam, Lon Nol ruled Cambodia until 1975. Like his predecessor, Lon Nol used anti-Vietnamese rhetoric to bolster his legitimacy in usurping power from Sihanouk..$^{90}$

Cambodia engaged in skirmishes with North Vietnam throughout the Lon Nol regime. ${ }^{91}$ When North Vietnam attacked Cambodia from 1970 to 1972, the relatively weak Cambodian forces faced one of the best armies in Southeast Asia. ${ }^{92}$ Afraid that North Vietnam would colonize Canbodia if it won the war in South Vietnam, Lon Nol characterized the war against Hanoi as crucial for the very existence of the Khmer race and culture. ${ }^{93}$ He called the North Vietnamese cruel and barbaric, and spread fear throughout the population by telling the Khmer people that Vietnam aimed to "systematically destroy our socioeconomic structure and our civilization," and "not simply to make our people subservient to them but to change our way of life, to modify our way of thinking and abolish our religious beliefs."

This "holy war against the Vietnamese ... turned into a campaign against all ethnic Vietnamese" living in Cambodia. ${ }^{95}$ This included about one-half million people, many of whom had been living in Cambodia since the time of French rule, and most of whom were, ironically, anti-communist. ${ }^{96}$ Nonetheless, as Elizabeth Becker notes, "centuries of defeat and humiliation..., the effect of the French patronizing of 'lazy' Cambodians while promoting 'industrious' Vietnamese, and the vivid fear of those 'industrious' Vietnamese taking over Cambodia had left their mark."97 Propaganda against the Vietnamese had the desired effect of spreading fear and hatred, as signs appeared in windows questioning the loyalty of the ethnic Vietnamese, and Khmers organized boycotts of ethnic Vietnamese businesses.98

When the time came to draft a new, post-coup Cambodian Constitution, Lon Nol advocated inclusion of a clause that would have allowed only racially pure Khmers to be considered Cambodian citizens. ${ }^{99} \mathrm{Be}-$

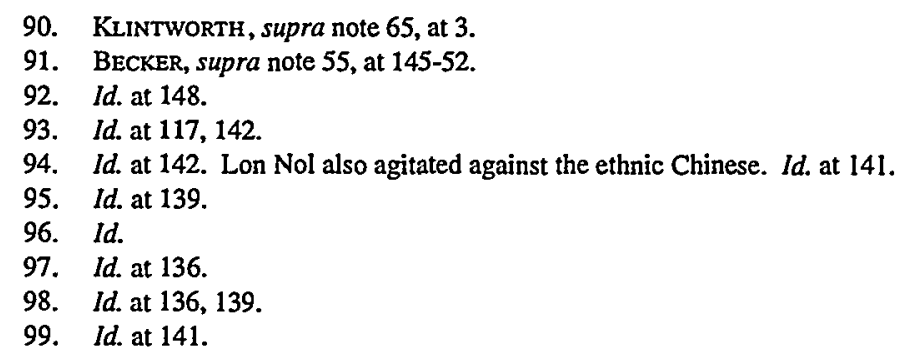


cause very few Cambodians would have met this criterion, other Cambodian legislators vetoed this clause. ${ }^{100}$ Still, the racist sentiment underlying the proposal remained an integral part of Lon Nol's regime. $\mathrm{He}$ continued to exalt the Khmer race and encourage the racism and xenophobia that drove his brutal government. ${ }^{101} \mathrm{He}$ also emphasized cultural differences between Vietnam and Cambodia in an effort to promote nationalism. ${ }^{102}$

The brutalities of the Lon Nol regime forced thousands to flee. ${ }^{103}$ Ethnic Vietnamese fishermen and traders were driven out of Cambodia; thousands of those who remained were massacred, their bodies dumped in the Mekong River. ${ }^{104}$ In May 1970, Lon Nol's army rounded up and killed thousands of Vietnamese civilians in and around Phnom Penh. ${ }^{105}$ Remarkably, no Cambodians publicly condemned the killings. ${ }^{106}$ Lon Nol continued to fan the flame of anti-Vietnamese antipathy among the Khmer population, leading to further massacres in ethnic Vietnamese villages. ${ }^{107}$

The government suspected many ethnic Vietnamese of treason solely on the basis of their ethnicity. ${ }^{108}$ Lon Nol placed those ethnic Vietnamese who were neither murdered nor expelled into detention camps and holding centers that resembled prisons. ${ }^{109}$ Lon Nol's campaign grew into a war against unarmed ethnic Vietnamese civilians whose families had lived in Cambodia for generations, ${ }^{110}$ as longestablished communities of ethnic Vietnamese were rounded up and forced into the camps. ${ }^{11}$

100. Id.

101. Id. at 136.

102. ChANDLER, supra note 59 , at 127.

103. Cambodia: Human Rights Before and After the Elections, supra note 54, at 20. In 1970 alone, 200,000 ethnic Vietnamese were expelled from Cambodia. Judith Banister \& E. Paige Johnson, After the Nightmare: The Population of Cambodia, in GENOCIDE AND DEMOCRACY IN СамBOdia, supra note 12 , at 65,72 .

104. ChANDA, supra note 58, at 71-72; Cambodia: Human Rights Before and After the Elections, supra note 54, at 20. In 1970, the bodies of 800 ethnic Vietnamese were found floating down the Mekong. Kiernan, supra note 12, at 239. Years later, an ambassador to Cambodia stated that in hindsight, the world should have seen these massacres as "a very ominous sign of things to come." David P. Chandler, The Tragedy of Cambodian History: Politics, War, and Revolution SINCE 1945, at 203-04 (1991).

105. Chandler, supra note 104, at 203. In further examples of ethnic violence, Lon Nol soldiers entered a Catholic Vietnamese settlement in Churi Changwar in 1970 and killed 800 Vietnamese laborers, throwing the bodies into the river; the army also slaughtered Vietnamese in Prasaut. BECKER, supra note 55, at 140.

106. ChANDLER, supra note 104, at 203.

107. Cambodia: A Country Study, supra note 28, at $\mathrm{xxx}$.

108. BECKER, supra note 55, at 139.

109. Id. at 139-40.

110. ChandLer, supra note 104, at 203.

111. Cambodia: Human Rights Before and After the Elections, supra note 54, at 20. 
Lon Nol staked his reputation on a vow to rid Cambodia of the ethnic Vietnamese, which led to numerous border clashes with Vietnam. ${ }^{112}$ At the same time, however, age-old ethnic tensions resurfaced between South Vietnamese soldiers and the Khmer soldiers who had been recruited to fight the communists in South Vietnam. Khmers faced ethnic slurs, and Khmer lives were endangered when the equipment of Khmer soldiers was stolen before battle. ${ }^{113}$ The numerous disputes between Khmer and South Vietnamese soldiers led people to predict that after the war, South Vietnam would invade and conquer Cambodia, then its ally. ${ }^{114}$

\section{F. Khmer Rouge (1975-1978)}

The war with North Vietnam destabilized Cambodia and helped the Khmer Rouge, a guerrilla faction led by Pol Pot, to defeat Lon Nol and take control of Cambodia in 1975.115 The Khmer Rouge established the Republic of Democratic Kampuchea, a radical regime that sought to transform Cambodia instantaneously into a completely self-sufficient, communist society. ${ }^{116}$

Under the Khmer Rouge, the Cambodian people experienced "unmitigated suffering" due to starvation, evacuation, disease, and unjustified executions. ${ }^{117}$ Ultimately, the brutal and misguided programs of the Khmer Rouge led to the deaths of one to three million Cambodians $^{118}$ or, at a minimum, one-eighth of the Cambodian population, in what has been called auto-genocide. ${ }^{119}$ Seeking immediate ideological transformation, the Khmer Rouge forced people to transfer family and religious loyalties to the state. ${ }^{120}$ The Khmer Rouge abolished formal education, eradicated money, and ultimately destroyed the Cambodian economy. ${ }^{121}$ Cities, towns, and hospitals were evacuated, family life was

112. BECKER, supra note 55, at 132. In fact, Lon Nol lost half of Cambodia to North Vietnam during his regime. Id. at 137.

113. See id. at 140 .

114. Id.

115. See Chandler, supra note 104, at 220-35.

116. See, e.g., CAMBodia: A CounTry StUdy, supra note 28, at xxxi-xxxii; Seekins, stipra note 65, at 51-52. For a more detailed description of the Khmer Rouge regime, see CHANDLER, stipra note 104, at 236-72; David R. Hawk, International Human Rights Law and Democratic Kampuchea, in THE Cambodian Agony, supra note 1, at 118, 121-26.

117. Seekins, supra note 65 , at 6,51 . The Khmer Rouge executed people even for small crimes of desperation, like stealing food. See Lawyers Committee for Human Rights, Cambodia: The JUSTICE SySTEM AND Violations OF Human RightS 24 (1992). For an extensive discussion of human rights abuses under the Khmer Rouge, see KIINTWORTH, supra note 65 , at $60-65$, or see generally MiCHAEL VICKERY, CAMBODIA: 1975-1982 (1984).

118. CAMBodia: A Country Study, supra note 28, at xxxi-xxxii; Seekins, supra note 65, at 51; see also CHANDLER, supra note 104, at 236 (estimating the number of dead at over one million).

119. CHANDLER, supra note 104, at 1 .

120. See SILBER, supra note 67, at 62-65.

121. Id.; see ChANDLER, supra note 104, at 1, 247. 
virtually abolished, ${ }^{122}$ and children were taught to spy on adults and report all infractions to "Angkar," ${ }^{23}$ the Khmer Rouge organization.

People were forced to obey "Angkar" without really understanding what it was. ${ }^{124}$ Cambodia became like a "giant prison farm." 125 Many enemies of "Angkar" were sent to interrogation centers where the Khmer Rouge coerced confessions of alleged crimes against the state. ${ }^{126}$ The most notorious of these centers was Tuol Sleng, in Phnom Penh, where the Khmer Rouge tortured and murdered 20,000 people. ${ }^{127}$

The Khmer Rouge agenda was inherently xenophobic, ${ }^{128}$ as extreme nationalism and racial purity were essential to the Khmer Rouge goal of self-sufficiency. ${ }^{129}$ In their warped patriotism, the Khmer Rouge confused race with ideology, irrationally deciding that all minorities threatened the regime. ${ }^{130}$ Anyone who did not look, act, or speak Khmer was suspect; ethnic Chinese, Muslim Cham, and ethnic Vietnamese were all endangered. ${ }^{131}$

Drawing upon the traditional Khmer antipathy toward Vietnam, the Khmer Rouge particularly targeted the ethnic Vietnamese for persecution. ${ }^{132}$ The Khmer Rouge used Vietnam, a plausible enemy, as a convenient scapegoat to distract people from Khmer Rouge failures and atrocities. ${ }^{133}$ The Khmer Rouge held cadre meetings to discuss the alleged Vietnamese threat. ${ }^{134}$ Vietnam rhetorically served as a mastermind power with a network of spies throughout Cambodia. ${ }^{135}$ The Khmer

122. Headley, supra note 28 , at 75 .

123. Id. at 57 .

124. ChandLer, supra note 104, at 254. Angkar was compared to a giant pineapple, because of its thousands of "eyes." See id. at 260. Thus, to a certain extent, Angkar presented the Cambodian equivalent of a mysterious and omnipresent "Big Brother".

125. Id. at 239.

126. Id. at 285-86.

127. LAWYers COMMITTEe for Human Righrs, supra note 117, at 25.

128. Banister \& Johnson, supra note 103 , at 74.

129. BECKER, supra note 55, at 253. Scientifically, no race is genetically "pure." For example, ethnic Khmers are of mixed Negroid, Mongoloid, Australoid, Malay, European, Chinese, and Vietnamese descent. Thus, even the premise of racial purity is untenable. Id.

130. Id.

131. Id.; Gregory H. Stanton, The Cambodian Genocide and International Law, in GENOcIDE and Democracy in Cambodia, supra note 12, at 141.

132. Cambodia: A Country Study, supra note 28, at xxxii; Seekins, supra note 65 , at 55 . This hatred of the ethnic Vietnamese, which included Vietnamese within Cambodia as well as Vietnamese in Vietnam, overrode any ideological kinship. BECKER, supra note 55, at 165; KLINTWORTH, supra note 65 , at 7 .

133. See BECKER, supra note 55, at 300-02, 311; CHANDA, supra note 58, at 68 . At one point, Ieng Sary, one of the leaders of the Khmer Rouge, even claimed the evacuation of cities under the Khmer Rouge was motivated by fear of the Vietnamese, despite the fact that the relationship between Vietnam and the Khmer Rouge was friendly at the time of evacuations in 1975. WILLIAM Shawcross, The Quality of Mercy: Cambodia, Holocaust and Modern Conscience, 33435 (1984).

134. See BECKER, supra note 55, at 326; see also SiLBER, supra note 67, at 44-45.

135. BECKER, supra note 55, at 311-12. 
Rouge promulgated the theory that the ethnic Vietnamese were savages waiting to swallow Cambodia at any opportunity, as they had done with Kampuchea Krom centuries before. ${ }^{136}$ The Vietnamese were allegedly poised to strike: there were rumors of Vietnamese attacks, and the Vietnamese were blamed for stealing Cambodian rice during a period of near starvation. ${ }^{137}$

One hundred fifty thousand ethnic Vietnamese fled soon after the Khmer Rouge took over Phnom Penh. ${ }^{138}$ The government expelled thousands of others to Vietnam. ${ }^{139}$ By the end of 1975, most ethnic Vietnamese had left their homes in Cambodia for Vietnam. ${ }^{140}$ Those who did not flee were killed. ${ }^{141}$ Like Lon Nol, the Khmer Rouge had an ethnic purification program, by which they aimed to eliminate the Vietnamese in their own version of a "final solution." 42 The Khmer Rouge even targeted people of mixed Khmer-Vietnamese ancestry in a genocidal campaign of massacres. ${ }^{143}$ Khmers returning from Vietnam were killed as "Vietnamese in Khmer skin." 144 Hundreds of thousands of innocent victims were harassed and murdered. ${ }^{145}$

In 1977, the Khmer Rouge ordered the mass execution of all remaining people of Vietnamese ancestry. ${ }^{146}$ The Khmer Rouge killed virtually all remaining ethnic Vietnamese, as well as Khmers who spoke Vietnamese or had Vietnamese friends, in the name of state security. ${ }^{147}$ After coercing their confessions at Tuol Sleng, the Khmer Rouge also killed those suspected of being Vietnamese agents. ${ }^{148}$

The Khmer Rouge began attacks on Vietnamese territory and civilians in $1975,{ }^{149}$ in an effort to regain Kampuchea Krom and Saigon. ${ }^{150}$ The Khmer Rouge advocated that each Cambodian soldier should kill

\footnotetext{
136. Id. at 302 .

137. Id. at 299.

138. ChANDA, supra note 58 , at 16 .

139. Id. at 256; Banister \& Johnson, supra note 103, at 74.

140. BECKER, supra note 55 , at 256.

141. See Stanton, supra note 131 , at 141 ; BECKER, supra note 55 , at 252-53.

142. Chanda, supra note 58 , at 86 .

143. Hawk, supra note 116, at 130.

144. BECKER, supra note 55 , at 192.

145. Id. at 254; see Seekins, supra note 65 , at 55 .

146. BECKER, supra note 55, at 252.

147. ChANDA, supra note 58, at 86. After an abortive coup, the Khmer Rouge killed as many as 100,000 Khmers they labeled as "Khmer bodies [with] Vietnamese minds." Seekins, supra note 65, at 66. Prior to many executions, the Khmer Rouge coerced confessions from the Khmers who supposedly had collaborated with the Vietnamese, thus providing "evidence" that: 1) they had "Vietnamese minds," 2) Vietnam was again meddling in Cambodian politics, and 3) an underground party aimed to sabotage the Khmer Rouge and tum Cambodia over to Vietnam. See BECKER, supra note 55 , at 310-11.

148. See BECKER, supra note 55, at 294.

149. Seekins, supra note 65 , at 66-68.

150. See, e.g., id. at 69; ChANDA, supra note 58, at 96.
} 
thirty Vietnamese people. According to Khmer Rouge leaders, while this plan could result in the loss of approximately 2 million Cambodian lives, the strategy would ensure the elimination of the entire Vietnamese population (approximately 50 million people) and allegedly force the return of lost territory. ${ }^{151}$ Beginning in 1977, the Khmer Rouge ruthlessly invaded and destroyed villages within Vietnamese territory and massacred civilians in these villages. ${ }^{152}$ The Khmer Rouge refused to negotiate a peace settlement with Vietnam. ${ }^{153}$ Instead, on December 31, 1977, the Khmer Rouge severed diplomatic ties with Vietnam, after refusing to accept Vietnam's proposal to resolve a border dispute. ${ }^{154}$

\section{G. People's Republic of Kampuchea (PRK) (1979-1991) 155}

The combination of the aggressive Khmer Rouge incursions into Vietnam and the slaughter of the ethnic Vietnamese minority in Cambodia prompted the Vietnamese invasion of Cambodia in $1978 .{ }^{156}$ With one of the best standing armies in Asia, Vietnam was able to force out the Khmer Rouge with little effort.

Heng Samrin led the Vietnamese forces. Heng was a Khmer who had served under the Khmer Rouge but was forced to escape to Vietnam when his own life was threatened during Khmer Rouge purges. ${ }^{157}$ Joined by Hun Sen as foreign minister ${ }^{158}$ and Chea Sim as vice president, ${ }^{159}$ Heng served as president under the new PRK regime. ${ }^{160}$ This patchwork regime was comprised of Khmer Rouge defectors, former

151. Seekins, supra note 65, at 69; Marlow Hood \& David A. Ablin, The Path to Cambodia's Present, in The Cambodian Agony, supra note 1, at Xv, xl; Silber, supra note 67, at 47.

152. Chanda, supra note 58, at 5, 97; Lawyers Committee for Human Rights, KAMPUCHEA: AFTER THE WORST 3 (1985); Kiernan, supra note 12, at 192.

153. Kiernan, supra note 12, at 192.

154. BECKER, supra note 55, at 319; see also CHANDA, supra note 58, at 297.

155. The PRK regime changed its name to State of Cambodia (SOC) in 1989 partially as a public relations move to distance itself from Vietnam before the anticipated election. See David A. Ablin, Introduction to the 1990 edition, in THE CAMBODIAN AGONY, supra note 1, at 415, 422-23. Former members of the PRK regime ran as members of the Cambodian People's Party (CPP). See infra note 180 and text accompanying notes 221-224.

156. Seekins, supra note 65 , at 6 . The Khmer Rouge basically taunted Vietnam until invasion was the only option. BECKER, supra note 55, at 439 . The Khmer Rouge used the Vietnamese invasion as an opportunity to foment anti-Vietnamese hatred among the Khmers. Over the radio, the Khmer Rouge accused the Vietnamese of looting and stealing rice, burning houses, stealing property and livestock, and raping and killing women; the broadcasters explained this behavior as a product of traditional Vietnamese hatred and contempt for the Cambodians. Id. at 319. The Khmer Rouge also held mass meetings to discuss the Vietnamese threat. See id. at 326.

157. ChaNDA, supra note 58, at 197-98.

158. ShawCross, supra note 133, at 109. Hun Sen was also a Khmer Rouge defector who fled to Vietnam in 1977 to escape Khmer Rouge purges. Chanda, supra note 58, at 197 . Hun Sen became foreign minister under the PRK and is currently one of the prime ministers of Cambodia.

159. VICKERY, supra note 117 , at 203. Chea Sim currently heads the Cambodian People's Party in Cambodia under the coalition government.

160. BECKER, supra note 55 , at 405 . 
Khmer Rouge who strategically shifted their alignment to the PRK after the invasion, Hanoi Communists, and returning non-communist Cambodian refugees. ${ }^{161}$ By 1980 , with 150,000 Vietuamese soldiers inside Cambodia, Hanoi held heavy influence over the new Cambodian government. ${ }^{162}$

Vietnam justified this invasion by claiming that it was necessary for Vietnam's self-defense and by referring to the hatred of the Khmer Rouge within Cambodia. ${ }^{163}$ In fact, many Cambodians welcomed the Vietnamese army as liberators, preferring the PRK to the Khmer Rouge. ${ }^{164}$

After taking power, the PRK faced the staggering task of restoring Cambodia in the face of famine, suspicion, and political opposition. ${ }^{165}$ The Khmer Rouge essentially had destroyed the entire country. Virtually no food, water, or usable infrastructure existed. ${ }^{166}$ Despite these obstacles, the PRK generally improved living conditions in Cambodia. ${ }^{167}$ They ended many Khmer Rouge policies, and allowed the return of family life, religion, and education for many people. ${ }^{168}$ They also held elections and drafted a new constitution. ${ }^{169}$ While there were numerous claims of human rights abuses under the PRK, ${ }^{170}$ the PRK administration was relatively moderate when compared with the Khmer Rouge, and Vietnamese troops were better behaved. ${ }^{171}$ The GNP of Cambodia rose $431 \%$ in the first four years of the PRK regime. ${ }^{172}$

161. Shawcross, supra note 133, at 36. Since 1977, Vietnam had recruited Cambodian refugees and Khmer Rouge defectors to unite in an effort to defeat the Khmer Rouge. BECKER, supra note 55, at 318 (describing recruitment of refugees); CHANDA, supra note 58, at 198 (describing recruitment of Khmer Rouge defectors).

162. BECKER, supra note 55, at 441 .

163. Id. at 355 (explaming self-defense as a rationale); Hood \& Ablin, supra note 151, at xlii-xliii (explaining Cambodian hatred of the Khmer Rouge as a rationale). The Victnamese bolstered their claim of self-defense by contending that the Chinese were planning to invade Vietnam through Cambodia. BeCKER, supra note 55, at 355.

164. E.g., SHAwCROSS, supra note 133, at 116 (quoting notes made by Jacques Beaumont, UNICEF envoy to Phnom Penh, in 1979, as stating that the "Vietnam army was and is still welcomed as liberator of the nightmare").

165. SILBER, supra note 67 , at 75 .

166. Ben Kieman, Introduction to GeNOCIDE aNd Democracy in Cambodia, supra note 12, at 10 (citing a 1979 report by Jean-Pierre Gallois, the first Western reporter in Cambodia after the fall of the Khmer Rouge); Banister \& Johnson, supra note 103, at 78.

167. SILBER, supra note 67 , at $85-90$.

168. Hood \& Ablin, supra note 151, at xlii-xliii.

169. Chanda, supra note 58, at 372 .

170. See BECKER, supra note 55, at $444-45$ ("A 1985 study of liuman rights abuses in contemporary Cambodia revealed an alarming record of arbitrary arrests, torture, imprisonment for political views and maltreatment in the prisons of the Phnom Penh regime, all under direct Vietnamese supervision." (citation omitted)).

171. See SILBER, supra note 67, at 94-96 (arguing that Vietnam turned over authority to Cambodians as quickly as possible and that Hanoi had no plan to colonize Cambodia). But see BECKER, supra note 55, at 444. Becker suggests that under the Heng Samrin regime, Vietnam's political aim of converting Cambodia to a docile, communist satellite of Hanoi took priority over 
Although the PRK eventually was able to improve conditions in Cambodia, many Cambodians still fled from their homeland to the Thai-Cambodian border, where they lived in refugee camps. ${ }^{173}$ Because Thailand was not a signatory to the United Nation's Protocol Relating to the Status of Refugees, ${ }^{174}$ the Thai government had no international legal obligation to aid Cambodian refugees. While the Thai government administered one of these refugee camps in conjunction with the UNHCR, it was unwilling to assume centralized control over the camps. Consequently, those camps not supervised by the Thai military were at the mercy of political guerrilla factions that sought to gain or regain control of Cambodia. ${ }^{175}$

After the invasion of Cambodia, few countries were willing to recognize the legitimacy of the PRK, largely due to Cold War politics. ${ }^{176}$ Instead, the international community recognized Prince Sihanouk as leading a government in exile. In 1982, Sihanouk (representing the Front Unis National pour un Cambodge Independant, Neutre, Pacifique, et Cooperatif, or FUNCINPEC), Son Sann (a Cambodian politician representing a resistance faction known as Khmer People's National Liberation Armed Forces), and the Khmer Rouge united to form the

rebuilding the country. Id. For support she cites examples of Vietnam's "near-colonial" control of Cambodia: some Cambodians were forced into labor gangs; Cambodian bureaucrats were required to attend indoctrination sessions in Hanoi; and Cambodians were required to send fish and rice to Vietnam, despite food shortages in Cambodia. Id. Between 1979 and 1989, however, Vietnam gradually loosened its control over Cambodia and withdrew its troops in a timely manner, contradicting claims that it had colonialist intentions. See CHANDLER, supra note 104, at 313.

172. SILBER, supra note 67 , at 86 .

173. While some fled because they feared the Vietnamese, many fled because of food shortages. Orlin J. Scoville, Rebuilding Kampuchea's Food Supply, in The Cambodian Agony, supra note 1, at 267, 268. Misguided Khmer Rouge policies had ravaged most farmland, little drinkable water existed, and many people's homes had been destroyed. SHAwCross, supra note 133, at 96-97. People were starving, and fear of famine was prevalent. LAWYERS COMMITTEE FOR Human Rights, Seeking Shelter: Cambodians in Thailand 24 (1987) thereinafter Seeking SHELTER]. Thus, many Khmers were forced to go to the border camps in search of food. CHANDLER, supra note 104 , at 313.

174. Jan. 31, 1967, 19 U.S.T. 6223, 606 U.N.T.S. 267.

175. Among the guerilla factions were the Khmer People's National Liberation Armed Forces, the Front Unis National pour un Cambodge Independant, Neutre, Pacifique, et Cooperatif (FUNCINPEC), and the Khmer Rouge. See Ablin, supra note 155, at 416. For a description of the hardships suffered at the camps, see generally SEEkING SHELTER, supra note 173, at 50-68, and Michael Vickery, Refugee Politics: The Khmer Camp System in Thailand, in The CAMBodian AGONY, supra note 1, at 293.

176. For example, China and Thailand helped rebuild the Khmer Rouge in an effort to strengthen resistance to the Vietnamese-supported PRK government. BECKER, supra note 55, at 440 . Both countries preferred to use Cambodia as a buffer zone to prevent continued Vietnamese expansion. See SILBER, supra note 67, at 91 (noting how policy considerations motivated China, the United States, and members of the Association of Southeast Nations (ASEAN) to support counter-PRK efforts inside Cambodia). 
Coalition Government of Democratic Kampuchea. ${ }^{177}$ The United Nations recognized the Coalition as Cambodia's official government in an effort to keep the Vietnamese occupation of Cambodia from becoming a fait accompli. During the remainder of the PRK regime, Sihanouk held Cambodia's U.N. seat in conjunction with the Khmer Rouge. ${ }^{178}$

\section{H. United Nations Transitional Authority in Cambodia (UNTAC) (1991-1993)}

Eventually, after years of international pressure, Vietnam agreed to withdraw its troops and to support free elections in Cambodia. There were many reasons why Vietnam was willing to leave: 1) the human, political, and economic costs of continuing its presence were extremely high; 2) Vietnam was unable to receive aid or foreign capital while its troops were in Cambodia; 3) Vietnam needed troops at home because of the security threat posed by China; and 4) pressure from the international community became unbearable. ${ }^{179}$ Moreover, the Khmer Rouge seemed unlikely to return to power, and the legitimacy of the PRK and its affiliated political party, the Cambodian People's Party (CPP), ${ }^{180}$ was enhanced because the international community recognized the CPP as a key player in the peace process. ${ }^{181}$

The Paris Peace Conference in August 1989 was attended by nineteen countries, including Vietnam, the People's Republic of China, Australia, the Lao People's Democratic Republic, the Kingdom of Thailand, France, and the United States, as well as four Cambodian political parties (CPP, FUNCINPEC, Buddhist Liberal Democratic Party (BLDP), and the Khmer Rouge). The purpose of the conference was to negotiate a settlement for the power struggle over Cambodia. ${ }^{182}$ In 1990, these talks were continued in New York and Paris, and an additional session was held in October 1991. These conferences resulted in the Paris Peace Accords ("Accords"). ${ }^{183}$ On October 23, 1991, the four competing Cambodian political factions signed the Accords, along with

177. CAMBOdia: A CoUntry Study, supra note 28, at xxxiv; Rinn-Sup Shinn, Government and Politics, in CAMBOdia: A CounTRY STUdY, supra note 28, at 185, 195.

178. BECKER, supra note 55, at 439, 443-44.

179. Amitav Acharya et al., Introduction to CAMBodia-The 1989 PARIS PEACE CONFERENCE, supra note 52 , at $\mathrm{xlv}$.

180. The CPP was formed prior to elections and was comprised of many former members of the PRK. In 1989, the PRK changed the name of their regime to State of Cambodia (SOC) in a public relations effort to distance themselves from Vietnam. Ablin, supra note 155 , at 422 . The decision to form the CPP and run under that party name rather than as the PRK may have represented a similar attempt by the PRK leaders to distance themselves from Vietnam. See generally Zachary Abuza, The Khmer Rouge and the Crisis of Vietnamese Settlers in Cambodia, 16 CONTEMP. SOUTHEAST ASIA 433 (1995).

181. See Archarya et al., supra note 179 , at xlv.

182. See id. at xxiii.

183. Supra note 45. 
the nineteen foreign nations represented, at which point the Accords immediately entered into force. ${ }^{184}$

The Accords created the United Nations Transitional Authority in Cambodia (UNTAC) to supervise elections and provide stability during the country's transition to democracy. ${ }^{185}$ The four Cambodian political parties formed the Supreme National Council (SNC) as the source of authority in Cambodia during the transitional period. ${ }^{186}$ However, after resuming pogroms against ethnic Vietnamese living in Cambodia, the Khmer Rouge withdrew from the peace process in $1993 .{ }^{187}$

Once again, the ethnic Vietnamese provided easy scapegoats for the Khmer Rouge. The ethnic Vietnamese received little if any sympathy from other Cambodians as the Khmer Rouge again preyed on Khmers' deep feelings of fear and antipathy toward the Vietnamese. ${ }^{188}$ Many ethnic Vietnamese who were former residents of Cambodia were returning home from Vietnam during this period, while other Vietnamese migrated to Cambodia to compete for UNTAC construction jobs. ${ }^{189}$ This wave of migration led to increased tensions between Khmers and all ethnic Vietnamese, including long-time ethnic Vietnamese residents. Racist diatribes in Khmer newspapers suggested that the ethnic Vietnamese should be forced back "to their country" because they were stealing from and destroying Cambodia. ${ }^{190}$ Racial violence against the ethnic Vietnamese thus remained an egregious human rights problem. ${ }^{191}$

The Khmer Rouge actions against the ethnic Vietnamese provoked little outrage or even criticism from other political factions, ${ }^{192}$ who employed similar anti-Vietnamese rhetoric and exploited anti-Vietnamese

184. Id. art. 30, 31 I.L.M. at 188.

185. Id. art. 1, 31 1.L.M. at 184 .

186. Id. art. 3, 31 I.L.M. at 184.

187. See Kiernan, supra note 166, at 20-21 (detailing racial pogroms undertaken by the Khmer Rouge in 1993 and suggesting that they had never seriously intended to engage in the peace process).

188. Kevin Barrington, Patient Khmer Rouge Hope the Memories Will Fade: Vietnamese Immigrants Present the Guerrillas with Easy Scapegoats, IRISH T1MEs, Apr. 9 \& 10, 1993, at 9.

189. See infra notes 265-76 and accompanying text.

190. Mark Dodd, Anti-Vietnamese Fever Rises in Cambodia, Reuter Library Report, Aug. 8, 1993, available in LEXIS, World Library, Reuter World Service File.

191. These brutal Khmer Rouge massacres of ethnic Vietnamese claimed 70 lives in 1993. U.S. Dep't of State, Country Reports on Human Rights For 1993, at 598 (1994) (report to House Comm. on Foreign Affairs and Senate Comm. on Foreign Relations) (hereinafter 1993 HuMAN RightS REPORT]. Innocent women, children, and elderly people were beaten to death or shot. A typical incident occurred on March 10,1993, in a floating village on the Tonle Sap in the Siem Reap province: twenty men entered the village at dusk on boats and opened fire with $\mathrm{AK}-47$ assault rifles on villagers in their houseboats, and in a video parlor for fifteen to thirty minutes. Eighteen people were killed and fifteen injured. Id. at 10.

192. Victor Mallet, Vietnamese Settlers in Cambodia Flee Attacks, FIN. TIMES, Mar. 31, 1993, at 4. Only after four major massacres did the provisional Cambodian government condemn the attacks. 1993 Human Rights Report, supra note 191, at 603. 
sentiment during the campaign. ${ }^{193}$ Prince Ranarridh (now the Cambodian first prime minister) called for virtual ethnic cleansing in Cambodia. ${ }^{194}$ Sihanouk responded to the massacres against the ethnic Vietnamese by stating that the only reasonable alternative for the ethnic Vietnamese was to leave Cambodia immediately for Vietnam. ${ }^{195}$ Newspapers predicted that if FUNCINPEC were to win, the ethnic Vietnamese would be forced to leave the country. ${ }^{196}$ Within the BLDP, Son Sann told the "Yuon," or Vietnamese savages, to "go home" and suggested that the ethnic Vietnamese should be rounded up and placed in detention camps to prevent them from voting in the elections. ${ }^{197}$

This rhetoric created an atmosphere so acrimonious that UNTAC officials feared that Khmer civilians would begin attacking the ethnic Vietnamese themselves. ${ }^{198}$ UNTAC officials warned that violence against ethnic Vietnamese during this period jeopardized the entire peace process, ${ }^{199}$ as fear of ethnic cleansing continued to spread. ${ }^{200}$

Vietnam repeatedly sought U.N. intervention to stop Khmer attacks on ethnic Vietnamese. ${ }^{201}$ U.N. Secretary General Boutros Boutros-Ghali told Vietnam that UNTAC would do everything possible to protect the ethnic Vietnamese within Cambodia. ${ }^{202}$ However, an UNTAC spokesperson stated that as UNTAC's mandate was to maintain, rather than to affirmatively create, peace under the Accords, UNTAC could only observe events in Cambodia; the provisional government was responsible for protecting the ethnic Vietnamese in Cambodia. ${ }^{203}$ Vietnam criticized this approach, asserting that under the Accords, the U.N. was responsible for protecting human rights and public security, and that the U.N.'s shirking of responsibility indirectly encouraged more violence. ${ }^{204}$

193. Mallet, supra note 192 , at 4.

194. Kiernan, supra note 12, at 243.

195. Id.

196. Tom Fawthrop, Cambodia: Ethnic Vietnamese Continue to Flee Cambodia, Inter Press Service, Apr. 8, 1993, available in LEXIS, World Library, Inter Press Service File.

197. Khmer Rouge Killing Ethnic Vietnamese in Cambodia, supra note 61.

198. Nick Cumming-Bruce, Terrified Vietnamese Fleeing the Cambodia that They Love, ObSERver (London), Apr. 11, 1993, at 14. This fear was borne out, for example, by the burning of Vietnamese homes and grenade attacks on Vietnamese cafes. See Cambodians Jeer as Vietnamese Flee, Reuters World Service, Mar. 11, 1994, available in LEXIS, World Library, Reuter World Service File; Khmer Rouge Wants Vietnamese Out of Cambodia, supra note 14.

199. Klimer Rouge Killing Ethnic Vietnamese in Cambodia, supra note 61.

200. See Yuli Ismartono, Cambodia: Racial Violence Raises Fears of Ethnic Cleansing, Inter Press Service, Mar. 30, 1993, available in LEXIS, World Library, Inter Press Service File.

201. Rogers, Cambodian Exodus Confronts Vietnam, supra note 17.

202. U.N. Chief Vows to Protect Vietnamese in Cambodia, USA TodAY, Apr. 12, 1993, at 6A.

203. Vietnam and Cambodia: Hanoi says UNTAC responsible for safety of Vietnamese; Cites Paris Agreement, BBC Summary of World Broadcasts, Voice of Victnam, Mar. 29, 1993, available in LEXIS, World Library, BBC Summary World Brdcast File.

204. Id. 
Meanwhile, the Khmer Rouge campaign of violence forced many ethnic Vietnamese whose families had lived in Cambodia for generations to flee Cambodia. An UNTAC official stated that ordinary Cambodians seemed happy that the Vietnamese were leaving, and that massacres of the ethnic Vietnamese reflected the will of the people. ${ }^{205}$ One Cambodian apparently expressed the sentiments of many when he told a reporter from the United States that he hated the Vietnamese, and was happy to see them go because they were like thieves, coming to rob and steal. ${ }^{206}$

\section{The Legacy of UNTAC}

On May 23-28, 1993, UNTAC supervised elections in Cambodia in what U.N. Secretary General Boutros Boutros-Ghali described as the largest and most ambitious U.N. operation ever ${ }^{207}$ FUNCINPEC received $45.5 \%$ of the vote, the CPP received $38.2 \%$ of the vote, and the BLDP received $3.8 \%$ of the vote. ${ }^{208}$ Upon criticism of the process and threat of secession by the CPP (who controlled the Cambodian military), ${ }^{209}$ FUNCINPEC agreed to form a coalition government with the CPP and the BLDP. Prince Rannaridh (of FUNCINPEC) was appointed as first prime minister, and Hun Sen (of the CPP, also formerly of the PRK) was appointed as second prime minister. ${ }^{210}$ Prince Sihanouk was made king, to reign but not to rule. ${ }^{211}$ The Provisional National Government drafted a constitution in 1993 establishing a liberal democracy and constitutional monarchy. ${ }^{212}$

\section{II}

ANALYSIS

Cambodia's background of anti-Vietnamese sentiment, along with the perceived threat of Vietnamese expansion, helps explain why some Khmer members of Parliament hesitate to grant nationality to the ethnic Vietnamese in Cambodia. The question remains whether the Cambodian government can legally justify either a mass deportation program or a discriminatory nationality law under Cambodian or international law.

205. McCarthy, supra note 49 , at A8.

206. Khmer Rouge Wants Vietnamese Out of Cambodia, supra note 14.

207. The Second Generation: Cambodian Elections 'Free \& Fair,' But Challenges Remain, UN Chron., Sept. 1993, at 32.

208. Id. at 33-34.

209. See Dodd, supra note 190.

210. 1994 HumAN Rights REPORT, supra note 17, at 548.

211. Id.

212. 1993 HuMAN Rights REPORT, supra note 191, at 597. 
Because it would be nearly impossible to implement a repatriation policy fairly, this Comment argues that Cambodia should abandon any such deportation plans. Instead, the government should more closely monitor the border if it aims to decrease immigration into Cambodia. At the same time, the government should adopt a non-discriminatory nationality law that will comply with Cambodia's human rights commitments while providing necessary definitions for Cambodia's current immigration law.

The following Sections will explore more fully the legal and evidentiary difficulties in applying the Geneva Convention to justify mass deportation of the ethnic Vietnamese from Cambodia and will suggest an alternative, non-discriminatory approach to nationality and immigration in Cambodia.

\section{A. Mass Repatriation: Cambodia's Legal Rights and Obligations} Under the 1949 Geneva Convention Relative to the Protection of Civilian Persons in Times of War (Geneva Convention) ${ }^{213}$

The Geneva Convention is a legal, moral, and humanitarian document that codifies the rules protecting civilians who find themselves in the hands of a party during a conflict or war when they are not nationals of that party. ${ }^{214}$ More specifically, the Geneva Convention aims to embody moral principles and to delineate specific legal rules that would protect civilians during war, accolnınodate military necessity, prevent the annexation of sovereign territory by force, and safeguard respect for humanity. ${ }^{215}$ Embodying customary international law, the Geneva Convention universally governs the behavior of those involved in armed conflict, regardless of whether any party has signed the Convention. ${ }^{216}$

The document was drafted in the shadow of Nazism solely to protect the rights and liberties of individuals. ${ }^{217}$ Because it does not grant a State any right to an individual's detriment, the Geneva Convention prevents an occupying power from transferring parts of its own population into occupied territory. ${ }^{218}$ One can interpret this clause to preclude the annexation of conquered territory through colonization.

Recently, members of the Cambodian parliament (MPs) who promote human rights in other situations have publicly supported the goal

213. Geneva Convention, supra note 47.

214. Id. art. 4, 6 U.S.T. at 3520, 75 U.N.T.S. at 290.

215. Jean Pictet, Humanitarian Law (1975) at 11, 17; Geneva Convention, supra note 47, at preamble.

216. See Theodor Meron, On the Inadequate Reach of Humanitarian and Human Rights Law and the Need for a New Instrument, 77 AM. J. 1NT'L L. 589, 596-97 (1983); P1CTET, supra note 215, at 11, 15.

217. PICTET, supra note 215 , at 19-21.

218. Id.; see Geneva Convention, supra note 47, art. 49, 6 U.S.T. at 3548, 75 U.N.T.S. at 318. 
of mass deportation and have relied on the Geneva Convention for legal justification. ${ }^{219}$ For example, while participating in a round-table discussion on the immigration law at the Foreign Correspondents Club in Phnom Penh, one such MP noted that Vietnamese forces invaded Cambodia in late 1978 and remained during the PRK regime until roughly 1989. He argued that during occupation, Vietnam breached the Geneva Convention by transferring part of its own civilian population into the Cambodian territory it occupied. He added that the Paris Peace Accords required all "foreign forces" to leave Cambodia. Interpreting the Geneva Convention and Paris Peace Accords in tandem, he concluded that under international law, all settlers who entered Cambodia during the period of occupation should be obligated to leave with the occupying forces. ${ }^{220}$

While this argument is considerably more sophisticated than Sihanouk's claim that all ethnic Vietnamese are really soldiers and thus should be driven from Cambodia, this Comment nevertheless argues that there are several reasons why the Geneva Convention should not be utilized to justify mass repatriation of the ethnic Vietnamese. First, although the Geneva Convention prohibits an occupying power from bringing civilian settlers into the occupied territory, it is unclear whether Vietnam actually occupied Cambodia during the PRK period within the meaning of the Geneva Convention. Second, even if Vietnam did occupy Cambodia during this period, the Geneva Convention does not suggest mass deportation of civilian settlers as an appropriate remedy. Third, even if the Geneva Convention is interpreted as allowing mass deportation of civilians as a remedy, the Cambodian government, due to lack of documentation and infrastructure, will be unable to identify definitively which Vietnamese people entered Cambodia in violation of the Geneva Convention, and which Vietuamese people entered Cambodia lawfully. In implementing a repatriation policy, the Cambodian government would risk ultimately deporting those who have the right to remain, even under the most expansive interpretation of the Geneva Convention.

\section{Applicability of the Geneva Convention: Foreign Occupation} and the (Il)Legitimacy of the PRK Regime

To show that the Geneva Convention is applicable, one must establish that the presence of Vietnamese troops in Cambodia amounted to occupation by a foreign force. This determination turns on whether the PRK is considered a legitimate Cambodian government or an unlawful

219. Speech at the Foreign Correspondents Club, Phnom Penh, (August 2, 1994) (notes on file with author).

220. Id. 
"puppet" regime installed by Vietnam. Unfortunately, this consideration is largely circular: whether the PRK regime is held to be legitimate colors how one views the presence of Vietnamese troops, and the presence of Vietnamese troops informs consideration of the PRK's legitimacy.

If the PRK was a legitimate regime of Cambodia, and Vietnamese troops were there at the PRK's invitation, and the presence of Vietnamese troops would not constitute foreign occupation. In that case, the ethnic Vietnamese who entered Cambodia during this period would have immigrated lawfully under the open immigration policy that existed under the PRK. Therefore, the Geneva Convention would not apply and should not be used to justify deportation of ethnic Vietnamese who entered Cambodia during this period.

On the other hand, some argue that the PRK government was an illegitimate "puppet" of Vietnam. This interpretation would make PRK support of Vietnamese troops irrelevant to whether the presence of troops constituted occupation. The illegitimate PRK government would simply be further evidence that Vietnam occupied Cambodia. The Geneva Convention would apply, although it would remain debatable whether the deportation of civilians would be a legitimate remedy.

The fact that PRK leadership was largely Khmer, not Vietnamese, helps bolster the legitimacy of the PRK regime. PRK leaders such as Heng Samrin, Chea Sim, Ouk Boun Cheoun, ${ }^{221}$ and Hun Sen were Khmer. ${ }^{222}$ Ironically, many members of the current government that condemns the PRK as foreign occupiers served in high positions in the PRK regime. For example, Chea Sim, the current head of the CPP and a member of Parliament, was vice president during the PRK regime. ${ }^{223}$ Hun Sen, currently the second prime minister of Cambodia, was a deputy prime minister of the PRK.224

221. Ouk Boun Cheoun served as Minister of Justice under the PRK. SHawcross, supra note 133 , at 357 .

222. See Kiernan, supra note 12, at 191; see also CHANDA, supra note 58, at 197. Moreover, Hun Sen represented the PRK in negotiations with Sihanouk. See Acharya et al,, supra note 179, at xxxviii; Shinn, supra note 177, at 235-36. Additionally, thousands of Khmers served under the PRK. Shawcross, supra note 133, at 357-58.

Vietnam was generally very lenient toward former Khmer Rouge cadres, and only released enough documentation to establish the personal guilt of Pol Pot and Ieng Sary. Id. at 359-60. Former Khmer Rouge soldiers were able to switch sides because blame for Khmer Rouge tragedies focused on leng Sary and Pol Pot rather than on other Khmer Rouge members involved at the time. For example, Pol Pot and leng Sary were the only Khmer Rouge officials charged with or tried for crimes against humanity by the PRK. Actually, the PRK appreciated having former Khmer Rouge in their regime, because they were already communist and therefore required less indoctrination. Id. at 35860.

223. Shinn, supra note 177 , at 208.

224. Id. at 209. The basis of the PRK's illegitimacy could be its having gained power through military force, rather than its composition. But there was no other way for them to obtain power in 
The overlap in leadership between the PRK and the current government supports the view that the conflict in Cambodia during the PRK regime was a domestic power struggle between competing Cambodian factions. Vietnam espoused this interpretation throughout the PRK regime and during the peace process. ${ }^{225}$ PRK leaders also held this stance. For instance, at the Paris Peace Conferences, Hun Sen, one of the current prime ministers of Cambodia, referred to the 1978 invasion as a Cambodian civil war to liberate Cambodia from the Pol Pot regime, with assistance from Vietnamese volunteers. ${ }^{26}$ Along these lines, a 1979 security treaty between the PRK and Vietnam required Vietnam to supply the troops ${ }^{227}$ that enabled the successful invasion of Cambodia and the ousting of the Khmer Rouge. 228 This Vietnamese assistance was crucial because the Khmer Rouge had crushed all internal resistance up to that time. ${ }^{229}$

Similarly, Vietnam saw its own role in Cambodia during the PRK as primarily advisory. ${ }^{230}$ Undeniably, Vietnam exercised heavy influence in Cambodia during the PRK regime. However, this assistance was essential in order to rebuild Cambodia after Khmer Rouge destruction. ${ }^{231}$ Vietnamese experts, such as political advisors, administrators, doctors, and teachers were needed to repair Khmer Rouge damage because the Khmer Rouge had killed most skilled and educated Cambodians. ${ }^{232}$

Others viewed such Vietnamese assistance as colonial expansion due to the prism of Cold War politics. Countries desiring a noncommunist buffer state between Vietnam and Thailand were unwilling

1979, as the Khmer Rouge certainly had no plans to call for democratic elections. See infra notes 226-29 and accompanying text.

Moreover, while the CPP gained power through UNTAC elections in 1993, they did not actually win the elections; FUNCINPEC did. FUNCINPEC agrecd to share power when the CPP, which controlled the military, threatened to secede. See supra note 209 and accompanying text. The amount of power the CPP currently holds may be disproportionate to the degree of popular support manifested in the elections. Thus, the magnitude of their influense in the current government could be similarly attributed to the presence of military force.

225. Acharya et al., supra note 179, at xxv. But see Shinn, supra note 177, at 224 (calling the civil war analysis a specious argument).

226. Hun Sen, Remarks at Paris Peace Conference, July 30, 1989, in Cambodia-The 1989 Paris Peace Conference, supra note 52, at $31,37$.

227. KIINTWORTH, supra note 65 , at 10.

228. See Acharya et al., supra note 179 , at xxv. It remains unclear whether Vietnam intended to conquer Phnom Penh, or only to oust the Khmer Rouge and took control of Phnom Penh merely because the Khmer Rouge provided them with a strategic opportunity. CHANDA, supra note 58, at 345,347 . Either way, Vietnam had its own security reasons to gain influence in Cambodia.

229. ChANDA, supra note 58, at 248. Consider, for example, the 100,000 Cambodians killed as "Khmer bodies with Vietnamese minds" by the Khmer Rouge during an uprising in eastem Cambodia. See id. at 254.

230. Acharya et al., supra note 179 , at $\mathrm{xx}$; Hun Sen, supra note 226 , at 37 .

231. Chanda, supra note 58 , at 371-72.

232. KLINTWORTH, supra note 65 , at 69-70. 
to recognize the PRK's legitimacy. ${ }^{233}$ Animosity toward Vietnam led many of these countries to view Vietnamese assistance as evidence that the PRK was a Vietnamese "puppet" regime through which Vietnam was occupying Cambodia unlawfully. ${ }^{234}$ Many of these same countries saw the Khmer Rouge as defenders of national sovereignty rather than as perpetrators of massive crimes against humanity. ${ }^{235}$

The international community did not uniformly adopt the belief that Vietnamese assistance constituted evidence of occupation. Debate flourished regarding who should be recognized as the legitimate ruler of Cambodia. ${ }^{236}$ For example, at the 34th session of the United Nations General Assembly in 1979, controversy surrounded the issue of whether the U.N. should recognize the PRK or the Khmer Rouge as the legitimate ruler of Cambodia. Eventually the U.N. accepted the Khmer Rouge, ${ }^{237}$ partially due to Chinese pressure. ${ }^{238}$ U.N. organizations such as UNICEF, however, were willing to work with Heng Samrin and Hun Sen, thus granting a degree of recognition to the PRK regime. ${ }^{239}$

233. See CHANDA, supra note 58, at 380-81. For example, ASEAN viewed the PRK as an instrument of Vietnamese control that had to be dismantled. Acharya et al., supra note 179, at xxvi. Sovereign nations such as those within ASEAN may have a vested interest in refusing to recognize the annexation of weaker countries by stronger ones, despite the fact that stronger countries are often able to invade and establish de facto control over weaker nations.

234. See SHawcross, supra note 133, at 330-31. Briefly, the Soviet Union supported Vietnam, the People's Republic of China backed the Khmer Rouge, and the United States aimed to undermine Vietnam and the Soviet Union. The United States also backed forees aiming to oust the PRK, including the Khmer Rouge. China opposed the PRK, because of PRK ties with Vietnam.

235. See id.

236. For example, at an international conference in Havana, the prospect of either the PRK or the Khmer Rouge taking the Cambodian seat created tremendous controversy because of disagreement regarding which faction legitimately represented Cambodia. Consequently, Cambodia's seat remained empty. SHAwcross, supra note 133, at 134.

In 1982, the Cambodian seat at the U.N. was granted to the Coalition Government of Democratic Kampuchea (CGDK), consisting of FUNCINPEC, Free Khmers, and the Khmer Rouge. KLINTWORTH, supra note 65 , at 8.

237. CHANDA, supra note 58, at 377-78; KLINTWORTH, supra note 65 , at 8.

238. SHAwcross, supra note 133, at 137-38. The PRK had received strong support from the USSR, while China supported the Khmer Rouge. Id. Many criticized the grant of the U.N. seat to the Khmer Rouge as an example of how the sovereignty interests of nations took precedence over concern for human rights at the U.N. Nonetheless, the Khmer Rouge attempted to persuade the Westem world to support it, arguing that Khmer Rouge support was necessary to overcoming the PRK in Cambodia. The Khmer Rouge tried to distance itself from Pol Pot during this period to gain wider international support. In particular, Khieu Samphan and Ieng Sary, two Khmer Rouge leaders, threw lavish parties at the U.N. and blamed Pol Pot for all the mistakes of their regime. Id. at 335 .

239. However, these international relief organizations faced political obstacles in helping the Cambodian people. Id. at 146-54. Hun Sen said, "We will do our best to cooperate [with international relief organizations] but would rather die than accept help that aims to divide our country into two parts." Id. at 165-66. Hun Sen further demanded that UNICEF and the Intemational Committee of the Red Cross not feed people on the border, where resistance factions aiming to topple his regime were amassing troops and lobbying for support. Id. at 143 . He declared that Cambodians would better starve to death than receive "poisoned assistance." Id. at 160-61. 
Moreover, when the United Nations Security Council explicitly called for the withdrawal of the Vietnamese from Cambodia, the Soviet Union vetoed this proposed resolution. ${ }^{240}$ The General Assembly, on the other hand, repeatedly called for the withdrawal of all foreign forces from Cambodia from 1979 until the Vietnamese troops ultimately departed in 1989.241

Opinion was divided not only within the U.N., but also within Cambodia. Many believed that the Vietnamese planned to stay permanently as masters, ${ }^{242}$ and that the PRK government no longer cared about the ordinary people of Cambodia. ${ }^{243}$ There were rumors of Vietnamese soldiers raiding and looting villages and stealing food to send to Vietnam. ${ }^{244}$ A pervasive feeling existed that the PRK favored the ethnic Vietnamese over the Khmers in Cambodia. ${ }^{245}$ Some felt that the Vietnamese liberators were becoming colonizers, and that Vietnamese were settling everywhere, enjoying more rights, controlling the economy, and taking public resources away from Khmers. ${ }^{246}$ While Vietnamese advisors were essential to Cambodia's rehabilitation, they often dictated decisions to Cambodian officials and exercised administrative control. ${ }^{247}$

At the same time, Westem journalists increased their rhetoric against the PRK, which in tum led Vietnam to downplay the extent of the hunger crisis. Id. at 153-54. It remains unclear how many more Cambodians starved due to this Cold War power struggle, which hindered relief efforts. See id. at 143,154 . However, the starvation faced by some during this period was ultimately a legacy of the Khmer Rouge. The Khmer Rouge not only destroyed the Cambodian system of agriculture, but also expelled or killed Vietnamese fishermen. A large source of food in Cambodia was thus left untapped because of the absence of skilled professional fishermen. Hood \& Ablin, supra note 151, at xlvi. Had the Vietnamese not invaded, the country would probably have remained under the control of Pol Pot; certainly many more Cambodians would have starved under Khmer Rouge rule. Politics aside, the Cambodian infrastructure remaining after the Khmer Rouge was inadequate to meet requirements for food distribution in Cambodia. See Shawcross, supra note 133, at 261.

The United States and Thailand undeniably preferred to distribute food at the border rather than enhance PRK legitimacy by working with Hun Sen. Hood \& Ablin, supra note 151, at XIv. Rice distribution at the Thai-Cambodian border, where the Thai army was in control, was also fraught with corruption and waste. Id. at xlvi. For example, food distributed at the border often went to members of the Khmer Rouge or other resistance groups, rather than to ordinary Cambodians. SHawcross, supra note 133, at 229 . Unfortunately, it seems that politics from all sides served to undermine humanitarian relief efforts.

240. SHAwCROSS, supra note 133 , at 76.

241. KLINTWORTH, supra note 65 , at 126.

242. Id. Vietnam reinforced this perception by calling the invasion "irreversible." Ablin, supra note 155 , at 419 .

243. See SHawcross, supra note 133, at 274.

244. Id. at 201.

245. Kampuchea: AFTER THE Worst, supra note 152, at $11 \mathrm{n} .11$. At the same time, some jobs could only be done by foreign workers because the Khmer Rouge killed many skilled Cambodians. See supra text accompanying note 232.

246. SHawcross, supra note 133, at 418-19. However, fewer ethnic Vietnamese lived in Cambodia at this time than before the pogroms and flight under Lon Nol and the Khmer Rouge. KLINTWORTH, supra note 65 , at 69.

247. ShawCross, supra note 133, at 418. For example, Vietnamese "experts" controlled Khmer prisons and guards. KAMPUCHEA: AFTER THE WORST, supra note 152, at 55. But see SILBER, supra 
Tensions increased between Cambodians and Vietnamese advisors within the PRK regime, as Cambodian gratitude for liberation gradually turned into resentment of imperialism. ${ }^{248}$

On the other hand, many Cambodians viewed the PRK as their liberators from the Khmer Rouge nightmare. Almost everyone had lost family members under the Khmer Rouge due to murder, starvation, or disease. ${ }^{249}$ Many scholars believe that most Cambodians ultimately would have died under the Khmer Rouge had Vietnam not intervened. ${ }^{250}$ Nearly all Cambodians initially saw the Vietnamese as saviors, and welcomed the Vietnamese troops because their arrival signaled an end to the Khmer Rouge. ${ }^{251}$ The PRK enhanced this perception of liberation by dramatically improving conditions within Cambodia. ${ }^{252}$ The PRK undoubtedly ameliorated tremendous suffering and prevented unnecessary deaths by taking relatively timely action to defeat the Khmer Rouge. ${ }^{253}$ Few Cambodians wanted the Vietnamese to leave, because they believed that the Khmer Rouge, who were rebuilding their strength along the Thai border, ${ }^{254}$ would regain power if Vietnam withdrew its troops. 255

Ultimately, there may be no way to resolve concretely whether Vietnam occupied Cambodia within the meaning of the Geneva Convention during this period, because opinion is so deeply divided and politicized. However, even if the PRK is considered a Cambodian regime, one must address the presence of 150,000 Vietnamese troops in Cambodia. In short, what interest did Vietnam have in providing troops if they were not interested in occupying Cambodia?

Some historians claim that Vietnam did not intend to colonize Cambodia, or even to keep troops there as long as it did; rather, the Vietnamese troops only remained because of fear that the Khmer Rouge would return to power if they left. ${ }^{256}$ Vietnam aimed to prevent the res-

note 67, at 96 (arguing that Vietnam turned control over to Cambodians as soon as possible and did not intend to "Vietnamize" Cambodia).

248. SHAWCROSS, supra note 133 , at 256.

249. ID.

250. See, e.g., ChANDA, supra note 58, at 370 . In fact, some argue that it would have been politically irresponsible for Vietnam not to invade Cambodia. SiLBER, supra note 67, at 133.

251. KLINTWORTH, supra note 65, at 8,66; Hood \& Ablin, supra note 151 , at xlii.

252. See supra text accompanying notes $165-172$. However, while the human rights climate improved dramatically under PRK rule, a pervasive pattern of human rights abuses still existed. KAMPUCHEA: AFTER THE WORST, supra note 152, at viii, 4, 29. The PRK sometimes showed disregard for the rule of law. Id. at 3-4. For example, torture occurred during interrogations. Id. at viii, 29. For a fuller description of human rights abuses under the PRK, see generally $i d$. at 11-108.

253. See KIINTWORTH, supra note 65 , at $46-47$.

254. SHawCROSS, supra note 133 , at 357.

255. KIINTWORTH, supra note 65 , at 8 .

256. Id. at 70. The need for humanitarian intervention is an ambiguous and controversial justification for invading another country under intemational law. KLINTwORTH, supra note 65, at 41 . 
toration of the Khmer Rouge not only for humanitarian reasons, but also for its own defense. ${ }^{257}$ Nonetheless, even within the rubric of a selfdefense justification, the question remains why Vietnamese troops stayed in Cambodia for almost a decade after the installation of the PRK

Generally, international law favors non-intervention with the internal affairs of a sovereign nation. See U.N. ChARTER, art. 2, III 2-4, 7. However, some scholars support international action when severe human rights abuses are occurring within a country. For a fuller discussion of this theory, see KLINTwORTH, supra note 65 , at 52-53,60-76. Certainly the threat of genocide, which violates jus cogens and conventional international law, would sufficiently justify foreign intervention in the view of these advocates. See id. at 52.

While this justification for humanitarian intervention has not risen to the level of customary international law, many human rights advocates support humanitarian invasion. See id. at 44-45. Within this paradigm of humanitarian invasion, some argue that the PRK should be considered a liberating rather than an occupying force, and that Vietnam therefore did not violate international law by invading Cambodia. Id. at 76 .

Under the justification of humanitarian invasion, international action coordinated by the U.N. would have been preferable to Vietnam's unilateral invasion of Cambodia. See id. at 46,74 . There was no chance of U.N. action against the Khmer Rouge, however, because China held a seat on the Security Council, and could have vetoed any proposed action against its ally. Id. at 46 . Further, the political will of the international community to prevent human rights abuses in Cambodia did not surface until over a decade after the Pol Pot regime ended. Id.

257. KLINTWORTH, supra note 65, at 60; ChANDA, supra note 58, at 401; Ablin, supra note 155 , at 419. Under the United Nations Charter, invading another country is not considered a violation of international law if the invasion is necessary for self-defense; on the contrary, the right to selfdefense is inalienable. U.N. CHARTER art. 2, TII 4,51; KLINTWORTH, supra note 65 , at 10 . Any invasion undertaken in self-defense, however, must be both necessary and proportional to the threat in order to be justifiable under international law. Id. at 16-17.

Some scholars argue that because the Khmer Rouge initiated hostilities and provoked Vietnam for years with racial insults and border attacks, the Vietnamese invasion slould be considered necessary and proportional to the cumulative threat posed by the Khmer Rouge and Clina. Id. at 1820, 24. The Vietnamese invasion can be interpreted as necessary for self-defense, because from Vietnam's perception, the "orgy of violence" in Cambodia against the ethnic Vietnamese, combined witl the Khmer Rouge attacks on Vietnam, were "part of a well-laid Chinese plan to crush Vietnam." Chanda, supra note 58, at 256.

There is some evidence to support this interpretation. Prior to the invasion, the Khmer Rouge were moving into the Mekong region, thereby threatening Vietnam's political and economic stability. KLINTwORTH, supra note 65, at 20. The Khmer Rouge and Clina were allies at the time; while the Khmer Rouge was orchestrating border incursions, China posed a greater security threat to Vietnam. See Chanda, supra note 58, at 201-02. As the Chinese-backed Khmer Rouge escalated attacks, the Vietnamese/Clinese border became less stable. KLINTwORTH, supra note 65, at 22-23. Vietnam needed to deal decisively with the Khmer Rouge, so it could focus its troops on China without the distractions provided by Khmer Rouge incursions. Id. at 25 .

The fact that Vietnam tried to negotiate with the Khmer Rouge, to no avail, further justifies the invasion under the doctrine of self-defense. Id. at 21. China was preparing for war with Vietnam just when the Khmer Rouge broke off diplomatic relations with Vietnam. CHaNDA, supra note 58, at 215-16. Vietnam feared that China was planning to invade Vietnam via Khmer Rouge-controlled Cambodia. When the Khmer Rouge refused to participate in proposed peace negotiations, Vietnam had to use other means to protect itself against Clinese invasion and the Khmer Rouge goal of Vietnamese extermination. KLINTwORTH, supra note 65, at 25-26.

Finally, the need to protect Vietnamese nationals may justify the Vietnamese invasion. However, this argument is controversial in interaational law. Moreover, remaining within Cambodia for ten years could be considered a disproportionate response. Finally, and most importantly, Vietnam did not and does not consider the ethnic Vietnamese in Cambodia to be Vietnamese nationals, so this argument would not apply. See id. at 35, 70-71. 
regime. Vietnam claimed that soldiers remained in Cambodia because the Khmer Rouge would not agree to their two demands: 1) that Pol Pot not return to Cambodia, and 2) that China cease to threaten Vietnam. ${ }^{258}$

While the above reasons may help to explain the presence of Vietnamese troops in Cambodia, it ultimately does not answer the question of whether Vietnam actually occupied Cambodia during the PRK period within the meaning of the Geneva Convention. Nonetheless, Cold War politics motivated numerous countries to oppose Vietnam, and consequently, to consider the PRK to be a unlawful puppet regime of Vietnam. Many Khmers currently support this interpretation. Thus, it is at least reasonable to argue that the Vietnamese government violated the Geneva Convention by bringing Vietnamese settlers into Cambodia during the PRK regime. However, even assuming this breach of the Geneva Convention, such a breach does not justify deportation of ethnic Vietnamese from Cambodia today. The next Section examines the proper remedy for breach of the Geneva Convention. It further argues that any interpretation of the Geneva Convention that utilizes the document to justify mass deportation violates the humanitarian spirit of the law.

\section{Appropriate Remedies under the Geneva Convention for Vietnamese Settlements in Cambodia During the PRK Regime}

The Geneva Convention does not discuss the proper remedy should an occupying power transfer civilian settlers into an occupied territory. Protocols to the Convention indicate that diplomatic protest or attempts to influence world opinion may be appropriate responses. ${ }^{259}$ Protocol I also states that compensation and reprisals against the power that breached the Convention may be appropriate in some situations, as long as any such reprisals were proportional to the original breach and respectful of the "law of humanity."260 Notably, Protocol I states that reprisals should not penalize protected civilians; rather, the belligerent party itself should suffer any necessary reprisals. ${ }^{261}$ Neither the Proto-

258. Kieman, supra note 12 , at 192.

259. Waldemar A. Solf \& Edward R. Cummings, A Survey of Penal Sanctions Under Protocol I to the Geneva Conventions of August 12, 1949, 9 CASE W. RES. J. INT'L L. 205, 206 (1977).

260. Id.: Protocol Additional to the Geneva Conventions of 12 August 1949, and Relating to the Protection of Victims of International Armed Conflicts, June 8, 1977, 1125 U.N.T.S. 3 [hereinafter ProtocoI I]; Stanislaw E. Nahlik, Belligerent Reprisals As Seen in the Light of the Diplomatic Conference on Humanitarian Law, Geneva, 1974-1977, LAw \& ConTemP. Probs., Spring 1978, at $36,43$.

261. Nahlik, supra note 260, at 46; see also Protocol 1, supra note 260, arts. 20, 48, 1125 U.N.T.S. at 15,25 . Of course, it may be a legal flction in international diplomacy that the international community can punish a state directly without in fact punishing the population within that state. The situation within Iraq provides just one example of how sanctions against a state ultimately harm the civilian population. See Anne Reifenberg, Oil-for-Food Deal Won't Leave Much For Iraq's Needy, 
cols nor the Geneva Convention itself mentions mass deportation of civilians six to sixteen years later as an appropriate response to breach. ${ }^{262}$

If the Geneva Convention does apply here, it could not be used as a tool for mass deportation without violating its underlying humanitarian goals. ${ }^{263}$ There is no convincing humanitarian justification for uprooting innocent civilians based upon a governmental policy from almost twenty years ago. Vietnam could be held accountable for violating the Geneva Convention, but any sanctions or reprisals should not be visited upon those ethnic Vietnamese civilians who have now lived in Cambodia for years. Cambodia should not force ethnic Vietnamese civilians to suffer reprisals, such as deportation, simply because the Vietnamese government may have breached the Convention. Any such reprisals upon civilians would be unsupported by either interpretive practice or legislative purpose. ${ }^{264}$

Finally, while some may argue that the Convention aims to prevent wartime annexation of sovereign territory, there is no evidence that Vietnam annexed Cambodian territory during the PRK. Even if Vietnam held heavy influence via a "puppet" regime, the Paris Peace Accords ensured the cessation of such influence. Vietnamese troops left Cambodia as required, and the Cambodian people elected a new Cambodian government. Thus, any threat of Vietnamese annexation or colonization presented by the PRK has dissipated. There is no need to deport ethnic Vietnamese civilians who consider themselves Cambodian to preclude Vietnamese annexation or future secession movements by the ethnic Vietnamese within Cambodian territory. So far as my re-

WALl STREet Journal, May 23, 1996. at A11. This is not a problem that can be solved within the scope of this paper. Moreover, even if targeting a state may indirectly harm its civilian population, this fact does not justify direct reprisals against civilians after breach by the state.

262. In fact, most discussions of breach revolve around prevention before and remedy during the breach, rather than damages after the breach. See generally Thomas J. Murphy, Sanctions and Enforcement of the Humanitarian Law of the Four Geneva Conventions of 1949 and Geneva Protocol I of 1977, 103 MIL. L. REV. 3, 60 (1984).

In addition, the Geneva Convention ceases to apply "on the general close of military operations." Protocol I, supra note 260, art. 3(b), 1I25 U.N.T.S. at 8. Because Vietnamese troops have left Cambodia, it is unclear whether the Geneva Convention applies at all. However, as proponents of mass deportation assume that the Geneva Convention does apply, it is worth establishing on the merits why the Convention cannot be used to justify mass deportation in Cambodia:

263. Moreover, while it is currently politically shrewd in Cambodia to condemn Vietnamese settlements, one should not ignore the fact that these settlers helped to rehabilitate Cambodia by enabling economic integration at a time when the Cambodian economy was decimated. See CHANDA, supra note 58, at 375-76.

While the Geneva Convention does preclude an occupying power from annexing territory through civilian settlements, this argument is not persuasive here, because the ethnic Vietnamese discussed in this paper consider themselves to be Cambodian and wish to be Cambodian nationals. As such, they do not serve as tools of Vietnamese expansionism at this stage of history.

264. In practice, those who violate the Geneva Convention are rarely prosecuted at all. Theodor Meron, Human Righrs and Humanitarian Norms as Customary Law 63 (1989). 
search can reveal, the Geneva Convention has never provided legal justification for the repatriation of individuals who consider themselves to be nationals of the country from which they are being deported.

\section{Evidentiary and Administrative Difficulties in Implementing Selective Deportation}

Even were deportation of illegal ethnic Vietnamese settlers an appropriate punishment for Vietnam's alleged violation of the Geneva Convention, such a plan would be hindered by serious administrative and evidentiary obstacles. The deportation agenda presupposes that the Cambodian government has the ability to determine when each ethnic Vietnamese person arrived in Cambodia, and to deport only those ethnic Vietnamese who entered unlawfully under the PRK. This task is made virtually impossible by the fact that different waves of Vietnamese have arrived in Cambodia at different points in history. ${ }^{265}$

A historical consideration of migration patterns into Cambodia shows that many ethnic Vietnamese have ties to Cambodia predating the PRK period. For example, the French recruited Vietnamese civilians to serve as civil servants and administrators during the colonial regime. ${ }^{266}$ Many ethnic Vietnamese currently in Cambodia have ties dating back to this period. In addition, during the PRK somewhere between 150,000 and 500,000 ethnic Vietnamese entered Cambodia. ${ }^{267}$ Other estimates state that 200,000 of the people who entered during the PRK were refugees returning to Cambodia, mostly from Vietnam. ${ }^{268}$ These ethnic Vietnamese fled from Cambodia to Vietnam in fear of their lives during

265. Although it may be difficult to determine exactly when individuals entered Cambodia, there are reliable statistics on the number of ethnic Vietnamese living in Cambodia at various points in history. These statistics help establish the extent of past immigration.

While ethnic Vietnamese did settle in Cambodia during the PRK, the ethnic Vietnamese population was smaller in 1992 than in the 1960s. Kieman, supra note 12, at 239. In 1950, 291,596 ethnic Vietnamcse lived in Cambodia, comprising seven percent of the population. Headley, supra note 28, at 108. In 1962, ethnic Vietnamese made up four percent of the Cambodian population, or 218,000 people. Banister \& Johnson, supra note 103, at 96-97. In 1965, this number was closer to 400,000 . Id. Before the Lon Nol massacres, 500,000 ethnic Vietnamese lived in Cambodia. ChANDA, supra note 58, at 375. Before the Khmer Rouge, the ethnic Vietnamese population was roughly 250,000-300,000. Seekins, supra note 65, at 85 . In 1984, this number was down to 56,000 . Id. Thus, the population after the PRK was still lower than in prior regimcs before the pogroms and expulsions of Lon Nol and the Khmer Rouge. Currently, it is believed that the ethnic Vietnamese constitute 5\% of the population. Stephen P. Marks, The New Cambodian Constitution: From Civil War to a Fragile Democracy, 26 Colum. HuM. RTS. L Rev. 45, 72 (1994).

266. See supra text accompanying notes 78-79.

267. Compare Meng-Try Ea, Recent Population Trends in Kampuchea, in The Cambodian AGONY, supra note 1, at 3, I0 (citing the number as between 300,000 and 500,000), with SILBER, supra note 67, at 96 (quoting David Jenkins, The Long Road Back: Phnom Penh Struggles to Rebuild a Shattered Nation, FAR E. ECON. REV., Nov. 29. 1984, at 30) (citing the number as between 150,000 and 200,000).

268. Shawcross, supra note 133 , at 311 . 
periods of pogroms against the ethnic Vietnamese in the 1970s; when the PRK took power, the refugees could safely return to Cambodia. ${ }^{269}$ Thus, many of the families who entered during the PRK had ties to Cambodia going back for generations. These ethnic Vietnamese were simply returning home, much like any other group of refugees. ${ }^{270}$ They were not settlers entering the country in violation of international law.

Additionally, approximately 3,000 Vietnamese fearing persecution fled from Vietuam to Thailand via Cambodia as refugees in the 1980s. ${ }^{271}$ They were known as the "land people" who settled in the border camps. The international community considered them refugees. ${ }^{272}$ The U.N. Convention Relating to the Status of Refugees, which Cambodia has signed, precludes Cambodia from sending them back to Vietnam, their country of origin and persecution. ${ }^{273}$ Because the Cambodian immigration law makes no provisions for identifying and providing asylum to refugees, the forced repatriation of all ethnic Vietnamese would violate this international legal commitment. ${ }^{274}$

Finally, prior to the UNTAC-supervised elections, many ethnic Vietnamese who had ties to Cambodia for generations fled their homes because of Khmer Rouge attacks on ethnic Vietnamese villages. Many later returned to Cambodia by land after the elections in $1993^{275}$ and should be allowed to stay in Cambodia. At the same time, thousands of ethnic Vietnamese came to Cambodia during UNTAC with the hope of benefitting from the economic boom in Phnom Penh. ${ }^{276}$ Arguably, if anyone should be forced to leave under an immigration policy, it should be these ethnic Vietuamese with no prior ties to Cambodia.

269. Cambodia: Human Rights Before and After the Elections, supra note 54, at 20.

270. Ea, supra note 267, at 10; KLINTWORTH, supra note 65, at 69; SILBER, supra note 67, at 96 (quoting Jenkins, supra note 267, at 30).

271. SEEKING SHelter, supra note 173, at 11, 66-67.

272. See SHAwCross, supra note 133 , at 409-10.

273. Convention Relating to the Status of Refugees, July 28, 1951, art. 33, 189 U.N.T.S. 150, 176. Contracting states shall not expel refugees lawfully in their territory unless necessary for national security or public order. Id. arts. $32,33,189$ U.N.T.S. at 174-76. No state of emergency has been declared by the King, as required by the Cambodian Constitution, to warrant such expulsions. Kingdom of Cambodia Const., art. 22. Moreover, under the Convention, due process is required prior to expulsion. Convention Relating to the Status of Refugees, supra, at art. 32, 189 U.N.T.S. at 174.

274. Sidney Jones, Executive Director of Human Rights Watch/Asia, notes the irony in this omission, given that hundreds of thousands of Cambodians were refugees after Pol Pot and relied upon the compassion of other nations' governmental officials in providing asylum. See Human Rights Group Warn of Possible New Abuses in Cambodia, supra note 39.

275. See discussion supra Parts I.F-I.H.

276. Cambodia: Human Rights Before and After the Elections, supra note 54, at 20; Branigin, supra note 6. Due to the current economic boom in Vietnam, many of the ethnic Vietnamese who came to Cambodia during this period solely to exploit economic opportunities are returning to Vietnam. The ethnic Vietnamese who are staying are primarily those who feel themselves to be Cambodian. Interview with Evan Gottesman, ABA Deputy Representative for Phnom Penh, in San Francisco, Cal. (Nov. 1995). 
Even if some of the ethnic Vietnamese living in Cambodia legally could be forced to leave in compliance with the Geneva Convention, Cambodian officials would not be able to identify which Vietnamese would be deportable. Lack of documentation and forgeries may preclude the determination of when, and under what circumstances, each immigrant entered Cambodia. 277 Many ethnic Vietnamese who once had identity papers showing ties to Cambodia dating back to Sihanouk's first regime have lost those identity papers during the past twenty-five years of instability. ${ }^{278}$ Due to these uncertainties, as well as the absence of a clear nationality law, officials may resort to discriminatory and/or arbitrary procedures to determine who can stay. Visual inspections and accent tests are likely, as are bribes and forgeries. In the end, many ethnic Vietnamese who should be allowed to stay in Cambodia could be forced to leave.

As a result, representatives of the UNHCR are opposed to systematic deportation. ${ }^{279}$ They consistently have refused to assist the Cambodian government in administering any deportation plan, and the Cambodian government currently does not have the resources to implement any such program on its own. However, nothing prevents Cambodian officials, be they members of the army or members of the police, from demanding bribes from ethnic Vietnamese, who would otherwise face further harassment or ad hoc expulsion. Similarly, nothing has prevented Cambodian officials from discriminating based on ethnicity in deciding who can leave and re-enter Cambodia. The situation at Chrey Thom provides a recent example of such discrimination. ${ }^{280}$

A non-discriminatory nationality law would help provide protection against such discrimination by legally protecting the rights of the ethnic Vietnamese in Cambodia and creating equal, cognizable rights for all Cambodian citizens. Although discriminatory enforcement may still occur, the formation of a clear legal rule would constitute an important and necessary step toward an orderly, democratic society based on rule of law.

277. Also, during the 1980 s, many Vietnamese prostitutes were trafficked involuntarily across the border to work in Cambodian brothels because Hanoi cracked down on prostitution. Interview with Cambodia Women's Development Ass'n in Phnom Penh (Aug. 5, 1994). Since these women were brought into Cambodia involuntarily, they should not qualify as part of the occupying force required to leave Cambodia under the Accords. Moreover, for humanitarian reasons, it seems particularly unjust to force these women to be involuntarily uprooted and victimized again because of politics only tangentially related to their lives.

278. Dobbs, supra note 38.

279. See supra notes $38-40$ and accompanying text.

280. See supra Introduction. 


\section{B. Cambodia's Legal Obligation to Pass a Non-discriminatory Nationality Law}

\section{The Paris Peace Accords}

In order to determine what a Cambodian nationality law should contain, one must look to the relevant legal commitments that Cambodia has undertaken. These include the Paris Peace Accords ("Accords"), the Cambodian Constitution, and human rights instruments such as the International Convention Against Racial Discrimination.

The Accords were developed in order to assist the orderly departure of Vietnamese troops from Cambodia, to ensure a peaceful transition toward democratic elections, and to restore and protect human rights in Cambodia. ${ }^{281}$ The Accords further aimed to create a liberal democracy in Cambodia based on pluralism. ${ }^{282}$ Crucial to the Accords was the concept that all people in Cambodia should enjoy the rights and freedoms embodied in the United Nations Universal Declaration on Human Rights and other human rights instruments. ${ }^{283}$

In particular, the Accords recognized that all Cambodians, including refugees and displaced persons, should be entitled to live in safety and security. ${ }^{284}$ Under the Accords, all Cambodians should hold the same rights and freedoms, including the right to move freely within Cambodia, to choose places of domicile and employment, and to own property. ${ }^{285}$ However, the Accords did not provide a definition of who should be considered "Cambodian," and thus who qualifies for certain delineated rights.

Because the word "Cambodian" rather than "Khmer" is used in the Accords, presumably people of different ethnicities can qualify for Cambodian nationality. Under this theory, "people" would refer to Cambodian nationals as well as others, while "Cambodians" would refer to Cambodian nationals of various ethnicities, not just Khmers. As the Accords clearly embody a non-discriminatory, pluralistic, and inclusive spirit, this interpretation would comport with the Accords' purposes and their underlying human rights principles. ${ }^{286}$ More concretely, several of the human rights instruments referred to in the Accords explicitly prohibit discrimination based on race or ethnicity ${ }^{287}$ Only a nondiscriminatory nationality law that allows for a multi-ethnic Cambodian population would be compatible with this principle.

281. See supra Part I.H.

282. Paris Peace Accords, supra note 45, annex 5, II 4, 3 I I.L.M. at 200.

283. Id. art. 15, 31 I.L.M. at I86.

284. Id. art. 20, 31 I.L.M. at 187.

285. Id. annex 4, I 4, 31 I.L.M. at 198.

286. For example, the Accords explicitly call for freedom from ethnic discrimination. Id. annex 5, $\mathbb{2}, 31$ I.L.M. at 200.

287. See infra notes $307-319$ and accompanying text. 
Further, the Accords specify that every person over eighteen years old either born in Cambodia or born to a person born in Cambodia is eligible to vote. ${ }^{288}$ The provision granting voting rights does not discriminate based on ethnicity. As voting rights are often linked to citizenship, by analogy a nationality law should not discriminate based on ethnicity, either.

Under international law, each sovereign state holds the inherent right to promulgate laws and regulations as it sees fit. Consequently, the Accords attempt to promote self-determination and national sovereignty for Cambodia. ${ }^{29}$ Cambodia should exercise its sovereignty by democratically passing laws that reflect the will of the Cambodian people. At the same time, such laws should be compatible with principles Cambodia has adopted in the Cambodian Constitution, the Paris Peace Accords, and other international agreements. ${ }^{290}$ As discussed below, it would behoove Cambodia to pass compatible laws as a way to encourage respect for law within Cambodia, and as a way to enhance its international reputation. These needs are particularly pressing in Cambodia, given its history of human rights abuses and its dependence on the goodwill of the international community for financial and technical support. Moreover, the Cambodian government should comply with the Accords in order to sustain its own power; undermining the Accords would nec-

288. Paris Peace Accords, supra note 45, annex 3, \$1 4, 31 1.L.M. at 197.

289. See id. at II, 3 I I.L.M. at 183 (Agreement on a Comprehensive Political Settlement of the Cambodian Conflict).

290. Theoretically, everyone who voted in the last election, including some ethnic Vietnamese, is represented in the National Assembly. Nevertheless, democratic rule could allow the majority to threaten the rights of a minority. In Cambodia, the official sanction of discriminatory inclinations may lead to disastrous human rights abuses against ethnic minorities. Depriving ethnic minorities of rights that stem from nationality will artificially shut them out of future political decisions, thus simultaneously threatening their freedom while undermining the democratic principles the Accords intended to further. Thus, it is important that even as democracy grows in Cambodia, international agreements should continue to provide baselines for the protection of human rights.

Some suspect that Cambodia did not really agree with these human rights principles, but mercly signed the agreements as a means of removing the PRK from Cambodia and ensuring the economic and political support of the international community. Indeed, Sihanouk himself spoke of "liberal democracy" mainly as a means to appease wealthy Western countries. Marks, supra note 265, at 57. The Cambodian government, however, has never stated that it was coerccd into signing these international agreements. Moreover, international law is consent-based. Even if consent were initially coerced, Cambodia could revoke its consent to any or all international agreements at any time. The government has not done so and is unlikely to do so in the future, because such an action would alienate the international community on which Cambodia relies for aid money.

The power of the purse may in itself be coercive. But the international community holds a finite amount of resources and must carefully choose where to invest money. A country that violates human rights may be less deserving of funds than a country that promotes human rights. Considering human rights records may thus be a basis for allocation decisions; use of such criteria to aid decisions may influence behavior, but cannot be considered inherently coercive when lack of resources requires difficult decisions to be made. Ultimately, Cambodia remains bound by signed international agreements, and the principles within them. 
essarily undermine the legitimacy of the government created as a direct consequence of the Accords.

Along these lines, under the Accords, Cambodia undertook responsibility to ensure respect for human rights and fundamental freedoms within its territory. ${ }^{291}$ To this end, Cambodia promised to take effective measures to guarantee that prior policies and practices of human rights abuse would never be repeated. ${ }^{292}$

Despite this promise, the Cambodian government still engages in rhetoric against the ethnic Vietnamese, and condones and encourages discriminatory treatment. ${ }^{293}$ Based upon Cambodian history, the government is ill-prepared to prevent discriminatory attacks if it simultaneously encourages discrimination against the ethnic Vietnamese through its own laws, policies, and rhetoric. Thus, in order to comply with its responsibilities under the Accords, the Cambodian government must take affirmative steps to protect the ethnic Vietnamese from private, as well as governmental, persecution.

While the government cannot necessarily prevent Khmer Rouge attacks on ethnic Vietnamese villages, a discriminatory nationality law would further marginalize the ethnic Vietnamese and preclude them from seeking government protection. A non-discriminatory Cambodian nationality law that grants ethnic Vietnamese nationality rights would better protect the ethnic Vietnamese.

\section{The Cambodian Constitution}

A discriminatory nationality law would be incompatible with principles enumerated in the Cambodian Constitution. The Accords outlined principles, such as freedom from ethnic and racial discrimination and human rights for all, ${ }^{294}$ on which the Cambodian Constitution was to be based. ${ }^{295}$ Consequently, the Constitution clearly states a commitment to democracy and pluralism, ${ }^{296}$ and guarantees human rights for all Cambodian citizens, regardless of race, color, birth origin, or any other status. The rights given the greatest protection include those stipulated in the U.N. Charter, the Universal Declaration of Human Rights, and other human rights Conventions. ${ }^{297}$

291. Paris Peace Accords, supra note 45, art. 15, 31 I.L.M. at 186.

292. Id.

293. This rhetoric can be considered incitement of racial hatred, which is prohibited by Art. 20 of the International Covenant on Civil and Political Rights, Dec. 16, 1966, 999 U.N.T.S. 171, 178, which Cambodia has ratified.

294. Paris Peace Accords, supra note 45, art. 15, annex 5, I 2, 31 I.L.M. at 186, 200.

295. Id. art. 15, Annex 5, 31 I.L.M. at 186, 199-200.

296. Kingdom of CAMBodia Const., art. 1 .

297. Id. art. 31 . 
In addition, Cambodian citizens are entitled to numerous specifically delineated rights. Every Cambodian citizen has the constitutional right to life, personal freedom, and security. ${ }^{298}$ Citizens shall not be deprived of their nationality or deported..$^{299}$ Citizens have the right to education; to full participation in the political, economic, social and cultural life of the nation; to choose their employment; to be protected against unlawful detention, prosecution or arrest; and to travel freely, settle abroad, and return to Cambodia. ${ }^{300}$

However, the Constitution does not define who can qualify for Cambodian citizenship. In the Cambodian language, the word for the Khmer ethnic group and "Cambodian" is the same. Thus, when the Constitution refers to rights held by Cambodians, it is unclear whether the language refers to members of the Kingdom of Cambodia or to members of the Khmer ethnic group. ${ }^{301}$

Justice Kirby, Special Representative of the U.N. Secretary General for human rights in Cambodia, noted that the security of the ethnic Vietnamese is threatened by this ambiguity. ${ }^{302}$ Because no law defines Cambodian citizenship, and because of the long-standing hostility toward the ethnic Vietnamese, many suspect that the National Assembly will interpret the phrase "Cambodian citizen" to exclude the ethnic Vietnamese. ${ }^{303}$ Some believe this ambiguous term purposefully was selected to allow and constitutionally justify such discrimination. ${ }^{304}$ Therefore, a nationality law that discriminates against the ethnic Vietnamese may be in harmony with legislative intent and constitutional history.

However, there are several reasons why the Constitution should be interpreted to allow non-Khmers to qualify for Cambodian citizenship. First, the Accords delineated the principles of pluralism and nondiscrimination on which the Constitution was to be founded. ${ }^{305} \mathrm{~A}$ broad interpretation allowing for a multi-racial Cambodian population would be more compatible with such underlying principles. Second, while itself containing no nationality clause, the Constitution nonetheless guar-

298. Id. art. 32.

299. Id. art. 33.

300. Id. arts. 35, 36, 38, 40, 65 .

301. See Marks, supra note 265, at 72-73.

302. Id. at 72.

303. Id.

304. Id. The drafters of the Constitution knew that this term was ambiguous, and the delineation of this term provoked great controversy. Some wanted "Khmer citizen" to include only Khmers. Others argued that "Khmer citizen" should also include the Chams and the hill tribes. No one argued that the term should include the ethnic Vietnamese. Ultimately, the drafters agreed to table discussion of "Khmer citizenship" and to define this term through future legislation. Constitution Debate "Hot" Over Human Rights Issues, Agence France Presse, Sept. 16, 1993, available in LEXIS, World Library, Agence France Presse File.

305. Paris Peace Accords, supra note 45, annex 5, I 2, 4, 31 1.L.M. at 200. 
antees human rights to all Cambodian citizens, regardless of race, color, birth origin, or other status. ${ }^{306}$ This clause suggests that the Constitution was drafted with the expectation that people of different races and ethnicities would be able to qualify for Cambodian citizenship. A nondiscriminatory nationality law would help fulfill this vision.

\section{Human Rights Conventions Ratified by Cambodia}

Cambodia has ratified numerous human rights conventions. ${ }^{307}$ These conventions provide even broader human rights protection than the Accords or the Cambodian Constitution. Many of these conventions protect all people in Cambodia, regardless of ethnicity, ${ }^{308}$ and specifically stipulate that signatories should not discriminate based on race or ethnicity. ${ }^{309}$

The most pertinent convention is the International Convention on the Elimination of All Forms of Racial Discrimination, which declares that all people are inherently equal and should not be subject to discrimination based on race, color, or national origin. Racial discrimination is defined as:

any distinction, exclusion, restriction or preference based on race, color, descent, or national or ethnic origin which has the purpose or effect of nullifying or impairing the recognition, enjoyment or exercise, on an equal footing, of human rights and fundamental freedoms in the political, economic, social, cultural or any other field of public life. ${ }^{310}$

306. Kingdom of Cambodia Const., art. 31.

307. These conventions include: 1) the Convention on the Prevention and Punishment of the Crime of Genocide, Dec. 9, 1948, 78 U.N.T.S. 277 [hereinafter Genocide Convention]; 2) the Convention and Protocol Relating to the Status of Refugees, supra note $174 ; 3)$ the 1nternational Convention on the Suppression and Punishment of the Crime of Apartheid, Nov. 30, 1973, 1015 U.N.T.S. 243; 4) the Convention on the Rights of the Child, Nov. 20, 1989, 28 I.L.M. 1448; 5) the International Convention on the Elimination of All Forms of Racial Discrimination, supra note 33; 6) the International Covenant on Civil and Political Rights, supra note 293; and 7) the Universal Declaration of Human Rights, G.A. Res. 217 (1II) A, U.N. Doc. A/810, at 71 (1948). Marks, supra note 265 , at 70, $94 \mathrm{nn} .151-52$. The Cambodian Constitution permits derogation from human rights norms in times of public emergency. See id. at 97 . However, King Sihanouk has not declared a state of emergency in Cambodia as required for this provision to come into effect.

308. See Marks, supra note 265 , at 70.

309. See, e.g., Convention on the Rights of the Child, supra note 307, art. 2, 28 I.L.M at 1459; International Covenant on Civil and Political Rights, supra note 293, arts. 2, 24, 26, 999 U.N.T.S. at 173, 179; International Covenant on Economic, Social and Cultural Rights, Dec. 16, 1966, art. 2, 993 U.N.T.S. 3, 5 .

310. Intcrnational Convention on the Elimination of All Forms of Racial Discrimination, supra note 33, art. 1(1), 660 U.N.T.S. at 216 . In addition, the Convention recognizes that discrimination on the basis of ethnic origin is disruptive to peaceful relations among nations. Id. preamble, 660 U.N.T.S. at 214. Thus, signatories resolve: 1) to adopt all necessary measures for speedy elimination of racial discrimination in all its forms, and 2) to prevent and combat racist doctrines and practices. See id. art. 2, 660 U.N.T.S. at 216-18. Each state should try to eliminate racial discrimination and promote understanding between the races. See id. art. 2(1), 660 U.N.T.S. at 216-18. To this end, 
In order to ensure compliance with the Convention, any Cambodian nationality law should not discriminate based on ethnicity.

International human rights instruments are rarely enforceable; the documents often represent goals and principles rather than administrable codes. ${ }^{311}$ The U.N., however, has created the International Committee on the Elimination of Racial Discrimination ("Committee") to supervise implementation of the Convention." The Committee is authorized to review reports on measures that signatories have taken to implement the Convention, ${ }^{313}$ and to investigate allegations of racial and ethnic discrimination. ${ }^{314}$ The U.N. authorized the Committee to issue an annual report on signatories to the Convention, which is presented to the General Assembly. ${ }^{315}$ The Committee also may make suggestions and recommendations for compliance with the Convention. ${ }^{316}$

As Cambodia remains dependent on the goodwill of the international community for technical assistance and financial aid, Cambodia cannot afford to pass a discriminatory nationality law, as such a law inevitably will attract attention and criticism from the Committee. On the other hand, because the Convention is not generally enforced, many other signatories allow de juris or de facto discrimination to flourish in their countries. It may seem unfair to single out Cambodia for blame while other countries breach such conventions without consequence.

The fact that other countries breach the Convention, however, cannot justify Cambodia's noncompliance. The U.N.'s involvement in Cambodia was motivated by recognition that the nation's history of atrocities mandated "special measures to assure the protection of hu-

states have agreed not to engage in any acts or practices of racial discrimination and to ensure that all public authorities and public institutions act in conformity with this obligation. Id. art. 2(1)(a), 660 U.N.T.S. at 218. States should condemn all propaganda and all organizations based on ideas of racial or ethnic superiority, or which attempt to justify or promote racial hatred or discrimination in any form. Jd. art. 4, 660 U.N.T.S. at 218-20. Moreover, states should not permit public authorities or institutions to promote or incite racial discrimination. Id. art. 4(c), 660 U.N.T.S. at 220. Civil rights, such as the right to nationality, should be granted without distinction based on race, or national or ethnic origin. $J d$. art. 5(d)(iii), 660 U.N.T.S. at 220 . Additionally, there should be no discrimination with regard to the right to medical care, cducation, or social services. Id. art. 5(e), 660 U.N.T.S. at 222.

311. On the other hand, international tribunals are attcmpting to hold Serbian and Rwandan leaders accountable for massive, orchestrated human rights violations. It remains to be scen whether such international tribunals are effective enforcement mechanisms.

312. Thomas Buergenthal, Implementing the UN Racial Convention, 12 Tex. INT'L LJ. 187, 187 (1977).

313. Id. at 188.

314. Frank C. Newman, International Control of Racial Discrimination, 56 CALIF. L. Rev. 1559, 1563 (1968).

315. Egon Schwelb, The International Convention on the Elimination of All Forms of Racial Discrimination, 15 INT'L \& CoMP. L.Q. 996, 1035-36 (1966).

316. Id.; Buergenthal, supra note 312 , at 198. 
man rights." 317 Due to its tumultuous history, Cambodia has earned special assistance and special scrutiny. Cambodia needs to foster an environment that will ensure respect for human rights. ${ }^{318}$ Because Cambodia is currently a country founded on the promise of respect for and cultivation of human rights, its nationality policy must be in accordance with human rights principles. ${ }^{319}$

\section{Further Reasons for Cambodia to Pass a Non-Discriminatory Nationality Law}

\section{Reaction from Vietnam}

Vietnamese and other Asian governmental officials fear that Cambodia intends to expel non-Khmers, ${ }^{320}$ and discrimination against the ethnic Vietnamese has recently "sent Hanoi into diplomatic overdrive" 321 and provoked official complaint from the Vietnamese government. ${ }^{322}$ Vietnamese officials expressed profound concern regarding the immigration bill even before it passed, ${ }^{323}$ because the Vietnamese government feared that the immigration law could be used to sanction mistreatment of the ethnic Vietnamese within Cambodia. ${ }^{324}$ Some feared

317. Cambodia: Human Rights Before and After the Elections, supra note 54, at 37; see United Nations Transitional Authority in Cambodia, Human Rights Component Final Report 1 (Sept. 1993); see also Paris Peace Accords, supra note 45, art. 16, 31 I.L.M. at 186 (discussing the need to foster an environment that will ensure respect for human rights, both during and after transitional period in Cambodia).

318. Many Khmers themselves have been subjected to racism as refugees or ethnic minorities. See generally SHAwCRoss, supra note 133, at 302-27. For example, Thai soldiers pushed Khmers over cliffs.

319. Cambodia has also signed the Genocide Convention, supra note 307. U.N. officials have stated that the massacres against the Vietnamese are comparable to genocide and other extreme crimes against humanity, and that anyone who does not take steps to prevent such tragedies may be held accountable under the Genocide Convention. Cambodia: UN Official Condemns Violence against Ethnic Vietnamese in Cambodia, BBC Summary of World Broadcasts, Vietnam News Agency, available in LEXIS, World Library, BBC Summary World Brdcast File. This may be mere hyperbole, as prosecution of the Kingdom of Cambodia under the Convention is unlikely. The underlying sentiment, however, is clear: Cambodia may be affirmatively required to prevent massacres of the ethnic Vietnamese under the Genocide Convention. Discriminatory laws would hinder performance of this duty by legitimizing and perpetuating the racism that motivates such massacres.

320. Greg Torode, Officials Fear for Settlers, South China Morning Post, Oct. 24, 1994, available in LEXIS, World Library, South China Moming Post File.

321. John Rogers, Pressure Will Stop Cambodian Evictions-Vietnam, Reuters World Service, Sept. 24, 1994, available in LEXIS, World Library, Reuter World Service File.

322. Torode, supra note 320 . Vietnam has also acknowledged that the only thing the Cambodian government can agree upon is "anything anti-Vietnamese." Id.

323. Vietnam Protests over Cambodia Immigration Bill, Reuters World Service, Aug. 26, 1994, available in LEXIS, World Library, Reuter World Service Library.

324. Vietnam, Cambodia to Hold Ministerial Talks Soon, Kyodo News Service, Japan Econ. Newswire, Oct. 20, 1994, available in LEXIS, World Library, Japan Economic News Wire File. 
that the law would lead to ethnic cleansing and genocide, with "unpredictable consequences." 325

Passage of the immigration law provoked immediate criticism from Vietnam as already-tense relations between Vietnam and Cambodia further deteriorated. ${ }^{326}$ The day after the law passed, Vietnam requested negotiations with the Cambodian government. ${ }^{327}$ Vietnam also sought assistance from the United Nations in protecting the ethnic Vietnamese in Cambodia, claiming that international action was warranted because the immigration law violated international conventions on human rights and the Paris Peace Accords. ${ }^{328}$

Vietnam is unlikely to threaten its own economic development, and potentially risk receipt of foreign aid, by using armed intervention to protect the ethnic Vietnamese. ${ }^{329}$ However, Vietnam already has implemented economic sanctions against Cambodia. For example, after the Cambodian government passed the immigration law, Vietnam closed the Mekong waterway and refused to allow cargo ships to go from Cambodia into Vietnam. ${ }^{330}$ In addition, Vietnam refused to grant transit permission to several ships bound for Cambodia. ${ }^{331}$ Vietnam denied a causal link between the immigration law and the trade problems, ${ }^{332}$ but Cambodian officials viewed the Vietnamese actions as retaliatory. ${ }^{333}$ The timing seems too perfect to be coincidental.

Cambodia seeks greater economic cooperation with Vietnam, ${ }^{334}$ which will become more important as Vietnam's market opens to international trade. Cambodia also seeks to increase technological coopera-

325. Vietnam Slams Cambodia's New Immigration Law, Kyodo News Service, Japan Econ. Newswire, Oct. 5, 1994, available in LEXIS, World Library, Japan Economic News Wire File.

326. Vietnamese and Cambodian Leaders Continue Contentious Talks, Agence France Presse, Jan. 16, 1995, available in LEXIS, World Library, Agence France Presse File.

327. Mark Dodd, Cambodia's Ranariddh Pledges No Mass Expulsions, Reuters World Service, Oct. 9, 1994, available in LEXIS, World Library, Reuter World Service File.

328. Hanoi Urges U.N. to Help Vietnamese in Cambodia, Reuters World Service, Sept. 6, 1995, available in LEXIS, World Library, Reuter World Service File.

329. See Rogers, supra note 32I. This may be an especially delicate time for Vietnam because its economy is opening up internationally, particularly due to normalized relations with the United States. These issues were not as pressing in 1979, when Vietnam last invaded Cambodia, because Vietnam was already suffering economic sanctions due to the Cold War.

330. Cambodia and Vietnam Settle Shipping Dispute, Reuters World Service, Dec. 1, 1994, available in LEXIS, World Library, Reuter World Service File; Seng Kimseang, Vietnam Strands Cambodian Ships, Reuters World Service, Nov. 7, 1994, available in LEXIS, World Library, Reuter World Service File.

331. Vietnam, Cambodia Negotiate Mekong River Commerce, Kyodo News Scrvice, Japan Econ. Newswire, Nov. 25, 1994, available in LEXIS, World Library, Japan Economic News Wire File.

332. John Rogers, Vietnam, Cambodia Shelve Key Issues in Hanoi Talks, Reuters World Service, Jan. 18, 1995, available in LEXIS, World Library, Reuter World Service File.

333. Cambodia and Vietnam Settle Shipping Dispute, supra note 330.

334. Cambodia Seeks Economic Cooperation with Vietnam, Reuters, Jan. 15, 1995, available in LEXIS. News Library, Wires File. 
tion between the two countries. ${ }^{335}$ Although moderately successful talks between Vietnam and Cambodia regarding river passage were held in Hanoi in January 1995, the two countries failed to resolve the crisis regarding the Cambodian immigration law. ${ }^{336}$ Ultimately, institutionalized racism embodied in the immigration law may hinder potential diplomatic progress between Vietnam and Cambodia.

Moreover, Cambodia currently holds observer status at the Association of Southeast Asian Nations (ASEAN), and would like to become a full member of this regional organization. If Cambodia alienates ASEAN members, such as Vietnam, by discriminating against or persecuting other southeast Asians because of their ethnicity, current members of ASEAN may hesitate to grant Cambodia membership.

\section{Reaction from the International Community}

Discrimination against the ethnic Vietnamese may hinder relations with the international community, upon whom the Cambodian government relies heavily for financial and technical assistance. U.N. Secretary General Boutros Boutros-Ghali responded to Vietnam's complaints by expressing his concern to the Cambodian government regarding the potential effects of the immigration law on ethnic Vietnamese in Cambodia, and by requesting that Cambodia negotiate with Vietnam. ${ }^{37}$ The Australian government expressed similar concern over the implications of the immigration law. ${ }^{338}$ Thailand urged Cambodia to proceed with caution. ${ }^{339}$ Meanwhile, a U.N. official in Cambodia accused the Cambodian government of being unwilling or unable to protect the ethnic Vietnamese, and condemned the government for repeatedly failing to investigate massacres of ethnic Vietnamese. ${ }^{340}$

International aid may diminish due to these shortcomings. In March 1995, representatives from forty donor countries and organizations met in Paris to discuss international aid to Cambodia. ${ }^{341}$ Although Cambodian Prime Minister Prince Ranardidh called for understanding,

335. See Cambodia, Vietnam Agree on Panels on Refugees, Border, Kyodo News Service, Japan Econ. Newswire, Apr. 3, 1994, available in LEXIS, World Library, Japan Economic News Wire File.

336. Leaders of Cambodia, Vietnam Hail Successful Talks, Kyodo News Service, Japan Econ. Newswire, Jan. 16, 1995, available in LEXIS, World Library, Japan Economic News Wire File.

337. Dodd, supra note 327.

338. Australia Shares Concern over Cambodian Immigration Law, BBC Summary of World Broadcasts, Vietnam News Agency, Sept. 21, 1994, available in LEXIS, World File, BBC Summary World Brdcast File.

339. Fawthrop, supra note 62.

340. Maja Wallengren, U.N. Body Warns of More Khmer Rouge Massacres, Reuters World Service, Oct. 21, 1994, available in LEXIS, World Library, Reuter World Service File.

341. Conference on Cambodia Aid Opens in Paris, Deutsche Presse-Agentur, Mar. 14, 1995, available in LEXIS, World Library, Deutche Presse-Agentur File. Estimates indicate that reconstruction of Cambodia will require over $\$ 200$ million. Id. 
conference participants considered the state of human rights in Cambodia in deciding whether to grant aid money. ${ }^{342}$ In fact, the Australian ambassador noted that the conference was actually a performance review, and warned Cambodia not to jeopardize international goodwill by abusing human rights. ${ }^{343}$

Participants specifically discussed abuses against the ethnic Vietnamese. ${ }^{344}$ Some suggested that monetary aid should be linked to a requirement of improved human rights conditions. Other groups have echoed this sentiment. For example, Human Rights Watch-Asia issued a report suggesting that Cambodian governmental officials should be held accountable for human rights abuses in Cambodia, including those against the ethnic Vietnamese. ${ }^{345}$ The report recommended that international financial institutions and other aid donors consider human rights conditions before donating money. ${ }^{346}$

The United States Congress recently approved the granting of Most Favored Nation (MFN) status to Cambodia. ${ }^{347}$ This action may indicate that the United States is primarily interested in promoting economic development and stability rather than human rights in Cambodia. On the other hand, perceived improvements in human rights conditions provided the impetus for granting Cambodia MFN status in the first place, thus demonstrating some link between human rights and trade status. ${ }^{348}$

The United States has been notably capricious with regard to its policies regarding trade and human rights. While human rights concerns ultimately failed to prevent the United States from granting MFN status to China, ${ }^{349}$ the power of the purse is much stronger in a country like Cambodia. Cambodia is one of the least developed countries in the world and requires millions of dollars of sustained international assistance to address its economic problems. ${ }^{350}$ Cambodia cannot afford to have its fragile economy jeopardized.

342. Denholm Barnetson, Donors Discuss Aid for Cambodia, UPI, Mar. 14, 1995, available in LEXIS, World Library, UPI File.

343. Matthew Grainger, Cambodia Must Protect Donors' Good Will: Aust, PhNom PenH Post, Mar. 10-23, 1995.

344. Bametson, supra note 342.

345. Human Rights Watch, Cambodia at War 10-11, 44-68 (1995).

346. Id. at 13.

347. Bill Archer, Most Favored Nation Treatment for Cambodia and Bulgaria, FED. DOCUMENT Clearing House, May 2, 1995, available in LEX1S, News Library, Cong. Press Releases File.

348. See Maja Wallengren, Cambodia Closer to Most Favored Nation Status, Reuters, Apr. 19, 1995, available in LEXIS, News Library, Wires File.

349. See Clinton Stresses Human Rights, Access Intellectual Property in Talks with Jiang, INT'L Trade Reporter, Nov. 24, 1993 at 1959, available in LEXIS, World Library, Int'1 Trade Reporter File.

350. Peter Tomsen, Cambodia: Recent Developments, 5 U.S. DEP'T ST. DisPatch 325 (1994) (statement before the Subcommittee on Asia and the Pacific. House Foreign Affairs Committee, May 11, 1994). 
Moreover, even if the United States does not link human rights conditions to economic aid and trade benefits, the United Nations and countries other than the United States may be more willing to do so. Given the record of human rights abuses in Cambodia, the international community felt a responsibility to prevent a return to the abuses and practices of the past. ${ }^{351}$ The international community spent tremendous time, money, and energy to help rebuild Cambodia. ${ }^{352}$ For example, UNTAC cost two billion dollars and was the biggest and most expensive U.N. mission to date. ${ }^{353}$ However, there are many problems throughout the world toward which the international community would like to direct its efforts. The international community has the responsibility to ensure that international aid money is not wasted on a government that acts in bad faith and erodes respect for international missions. It would behoove Cambodia to show the international community that it is serious about reforms by complying with its international commitments. ${ }^{354}$

The U.N. has noted that the position of the ethnic Vietnamese is a "major indicator" of human rights conditions in Cambodia. ${ }^{355}$ Human rights groups and international legal experts have cited the immigration law as an example of Cambodia's failure to adhere to its human rights obligations. ${ }^{356}$ The Cambodian government can encourage further international aid and prove to the international community its good-faith commitment to change and progress by fulfilling the human rights commitments it has undertaken and passing a non-discriminatory nationality law.

\section{The Situation Within Cambodia}

\section{a. Foreign Investment}

Just as Cambodia cannot afford to jeopardize its international aid money, it cannot afford to have foreign investors deterred by the appearance of instability within the country. Cambodian governmental officials know that negative human rights publicity threatens foreign investment. At a conference at the Foreign Correspondents Club, Minister of Information Ieng Mouly implored journalists to stop writing

351. See Makabenta, supra note 37.

352. Id.

353. Kieman, supra note 12 , at 12.

354. Rescinding all international aid in an effort to secure human rights could backfire and hurt impoverished civilians. See generally Chanthou Boua, Development Aid and Democracy in Cambodia, in Genocide AND Democracy in CAMBodia, supra note 12, at 273-83. To avoid this, the international community could decide to allocate aid to such programs as education and health care rather than to the government.

355. Sergei Blagov, Cambodian Govt to Let Ethnic Vietnamese to Return [sic], The Russian Information Agency ITAR-TASS, Jan. 23, 1995, available in LEXIS, News Library, Wires File.

356. Cambodia's Sihanouk Requests Changes to Law, Reuters World Service, Sept. 20, 1994, available in LEXIS, World Library, Reuter World Service Library. 
negative stories about Cambodia because such negativity threatened to impede foreign investment. ${ }^{357}$ Prime Ministers Hun Sen and Prince Ranariddh wrote a joint letter to U.N. Secretary General Boutros Boutros-Ghali, complaining that focus on and publicity regarding human rights abuses in Cambodia undermined foreign investor confidence, and asking the United Nations Center for Human Rights to leave Phnom Penh. ${ }^{358}$

These examples manifest a disturbing theme in Cambodian politics: instead of attempting to improve human rights in Cambodia, both the co-prime ministers and the minister of information seek to silence media exposure of human rights abuses to safeguard foreign investment. Human rights advocates and journalists logically argue that the Cambodian government should instead stop violating human rights if it is concerned about negative publicity. ${ }^{359}$

\section{b. Current Persecution of the Ethnic Vietnamese}

Governmental discrimination institutionalizes and perpetuates the racism that has traditionally led to pogroms and instability. Khmer Rouge massacres of ethnic Vietuamese prior to the elections caused U.S. Ambassador Charles Twinning to fear that Cambodian history may repeat itself. ${ }^{360}$ Twinning's concerns remain relevant as these pogroms continue without remedy. Since passage of the immigration law, ethnic Vietnamese in Cambodia once again have suffered a string of ethnicitybased attacks. ${ }^{361}$ For example, on October 20, 1994, shortly after the immigration law passed, the Khmer Rouge entered a village at night, woke suspects, and asked their names; anyone who replied with an accent was shot on the spot. ${ }^{362}$

These attacks prompted Vietnam and the U.N. to implore Cambodia to take effective measures to prevent further massacres by the

357. Speech at Foreign Correspondents Club, Aug. 2, 1994. Cambodia recently passed an extremely repressive press law, aimed at curtailing negative stories about the government. See Leah Makabenta, Cambodia-Media: Shooting the Messenger, inter Press Service, Dec. 17, 1994, available in LEXIS, World Library, Inter Press Service File.

358. Cambodia-U.N.: Criticism of U.N. Office Angers Rights Group, Inter Press Service, Mar. 20, 1995, available in LEXIS. World Library, Inter Press Service File.

359. Nate Thayer, Speech at Foreign Correspondents Club, Phnom Penh (June 23, 1994).

360. Kieman, supra note 12 , at 239 . These attacks were particularly savage and were conducted with "military precision"; babies were found with their hands shot off. Id. at 243. These massacres provoked responses from Vietnam and Laos, both of whom urged the U.N. and concerned countries to help protect the lives and property of ethnic Vietnamese in Cambodia. U.N. Urged to Protect Vietnamese in Cambodia, Reuter Library Report, Apr. 5, 1993, available in LEXIS, World Library, Reuter World Service File.

361. Torode, supra note 320.

362. See e.g., Wallengren, supra note 340. 
Khmer Rouge against the ethnic Vietnamese in Cambodia. ${ }^{363}$ A FrenchCambodian human rights group issued a statement saying that the situation in Cambodia had become intolerable, and urged the Cambodian authorities to take action to protect all people within Cambodia. ${ }^{364}$ Attacks against the ethnic Vietnamese on December 7, 1994 provoked similar protests. ${ }^{365}$ Ethnic Vietnamese in Cambodia lamented that the local authorities did nothing to protect them from such attacks. ${ }^{366}$

Since passage of the immigration law, ethnic Vietnamese have complained about a growing atmosphere of fear in Cambodia. Ethnic Vietnamese fishermen continue to face extortion from government soldiers. ${ }^{367}$ Provincial governmental officials continue to harass the ethnic Vietnamese and imply that they soon will be deported. ${ }^{368}$ For example, some officials have orderêd Vietnamese settlers to sell their properties to them cheaply because they soon would be leaving and no longer need the property. ${ }^{369}$

The immigration law provides for confiscation of identity cards, and Cambodian police reportedly have taken these cards from numerous ethnic Vietnamese. ${ }^{370}$ Under the immigration law, an ethnic Vietnamese can be deported within seven days after having his or her card seized. ${ }^{371}$ These seizures may increase unless the officials are bribed ${ }^{372}$ Ethnic Vietnamese villagers further lament that complaints made to the police or human rights groups have resulted in retaliatory treatment. ${ }^{373}$

Despite these practices of ad hoc persecution, the Cambodian government has nevertheless vowed to protect the ethnic Vietnamese in Cambodia. ${ }^{374}$ Prince Ranariddh has written to U.N. Secretary General Boutros Boutros-Ghali that the immigration law will not be used for

363. Human Rights Group Condemns Vietnamese Killings, Reuters World Service, Oct. 26, 1994, available in LEXIS, World Library, Reuter World Service File.

364. Id.

365. Rights Group Condemns Killing of Vietnamese, Reuters World Service, Dec. 12, 1994, available in LEXIS, World Library, Reuter World Service File.

366. Khmer Rouge Kill Seven Ethnic Vietnamese, Agence France Presse, Oct. 21, 1994, available in LEXIS, World Library, Agence France Presse File.

367. See Maja Wallengren, Ethnic Vietnamese Fear Extortion and Khmer Rouge, Reuters World Service, Sept. 20, 1994, available in LEXIS, World Library, Reuter World Service File.

368. See Torode, supra note 320 .

369. Id.

370. Dobbs, supra note 38.

371. Id.

372. See id.

373. Wallengren, supra note 367.

374. Cambodia Vows to Protect Foreigners, Reuters World Service, Jan. 17, 1995, available in LEXIS, World Library, Reuter World Service File. The government said it would protect ethnic Vietnamese, as well as other foreign residents. Id. Thus, the Cambodian government persists in viewing the ethnic Vietnamese as foreigners within Cambodian territory. 
mass deportation prior to Vietnamese-Cambodian talks on the subject. ${ }^{375}$ Prince Ranariddh has also stated that further sub-decrees or ministerial decisions are needed to implement the immigration law. ${ }^{376}$ Unfortunately, such sub-decrees have since been issued, and they further assist governmental officials in persecuting the ethnic Vietnamese.

On the other hand, after years of international pressure, the Cambodian government finally negotiated with Vietnam in January 1995 regarding the status of the boat people. At the time, it appeared that some of the boat people would be allowed to return to Cambodia. ${ }^{37}$ However, Cambodia only allowed the return of boat people holding identity papers predating $1970 .^{378}$ This requirement is much stricter than that suggested by either the U.N. Human Rights Envoy to Cambodia, Justice Kirby, ${ }^{379}$ or Cambodian human rights groups. ${ }^{380}$ Ultimately, the new governmental policy benefitted only thirteen families, ${ }^{381}$ who continue to face persecution within the country.

\section{c. Wasted Resources and Empty Economic Niches}

According to an UNTAC report, discrimination against minorities in Cambodia threatened to destabilize Cambodia in 1993. ${ }^{382}$ Such discrimination poses a similar threat today, if for no other reason than that government time and resources could be channeled more productively than by persecuting the Vietnamese. ${ }^{383}$

375. Anh Asks Sihanouk to Protect Vietnamese in Cambodia, supra note 48. Upon receiving complaints from Vietnamese President Le Cuc Anh and Prime Minister Vo Van Kiet, King Sihanouk called upon the National Assembly to amend the immigration law, despite the fact that he originally supported passage of the law. Dobbs, supra note 38. No amendment has yet been offered.

376. Don't Worry about Immigrant Law, Cambodia Says, Reuters World Service, Sept. 10, 1994, available in LEXIS, World Library, Reuter World Service File.

377. Blagov, supra note 355 . While the Cambodian government originally claimed that 4,000 people would be able to re-enter Cambodia, ultimately only about 100 people were allowed to return. See UNHCR, Note for the File, Mission to Cambodian-Vietnamese border (Chrey Thom) on 12 July 1995 (on file with author).

378. Id.

379. Tricia Fitzgerald, Cambodia Blocks Return of Ethnic Vietnamese, UPI, Jan. 21, 1995, available in LEXIS, World Library, UPI File.

380. Cambodian Human Rights Groups Urge Aid for Vietnamese, Reuter Library Report, Aug. 27. 1993, available in LEXIS, World Library, Reuter World Service File (explaining that human rights groups suggest that Vietnamese with papers dating back to 1975 be allowed into Cambodia).

381. UNHCR, supra note 377. At this stage, the number of people trapped at the border has decreased to approximately 2700 people. It is believed that the rest of the boat people sold their boats and either retumed to Vietnam or entered Cambodia illegally by land. Id.

382. The Human Rights Component: End of the Year Report for 1992, at 11 (UNTAC manuscript on file with author).

383. By focusing on the "Vietnamese forces," UNTAC undercut its own ability to protect these ethnic Vietnamese. Cambodia: Human Rights Before and After the Elections, supra note 54, at 21. For example, rather than protecting civilians, UNTAC hunted for alleged Vietnamese forces disguised as civilians for several months, hoping to win favor with the Khmer Rouge and securc its cooperation with the elections. Ultimately, UNTAC concluded that no foreign military forces 
Additionally, the Cambodian economy suffers from the absence of the ethnic Vietnamese, ${ }^{384}$ who fill an economic niche in Cambodia as fishermen and construction workers. The price of fish, the main source of protein in the Cambodian diet, skyrocketed when the ethnic Vietnamese fled in $1993 .^{385}$ The lack of Vietnamese construction workers forced a number of important building projects in Phnom Penh to halt. ${ }^{386}$ Cambodia can ill afford such disruptions while it is trying to encourage foreign investment. Political analysts agree that if Cambodia is to overcome its tragic situation, the efforts and resources of all Cambodians are essential, regardless of their ethnicity. ${ }^{387}$

The Cambodian government can help put an end to this destabilizing cycle of violence and racism by adopting laws and administering policies that support peace, pluralism, and acceptance. While the Khmer Rouge is often directly responsible for the violence, the Cambodian government supports and encourages the violence through its tacit approval and failure to investigate massacres or effectively protect the ethnic Vietnamese. A non-discriminatory nationality law would help to protect ethnic Vietnamese in Cambodia by creating equal and cognizable rights for all Cambodians.

remained. No concrete evidence of the presence of Vietnamese forces was ever produced by the Khmer Rouge.

Under heavy pressure from the Khmer Rouge, however, UNTAC declared that it had found three people who fit within the category of foreign forces under the Accords. These people were expelled from Cambodia, despite the fact that they were no longer members of the Vietnamese army, had married Cambodian women, and had been issued Cambodian citizenship cards by the SOC government. Id. at 22-23. One was an ethnic Khmer from Vietnam with a pregnant wife and four small children, who had served as an interpreter for the Vietnamese army and the SOC army, and was then working as a taxi motorcycle driver. He received death threats when his neighbors realized he had served in the Vietnamese army. Id. at 23. Five more men were later identified; Vietnam would not accept these people back, because they claimed the men had become Cambodian citizens.

By identifying a handful of men, UNTAC confirmed popular suspicion that demobilized Vietnamese soldiers remained in Cambodia and simultaneously undermined its own credibility by finding so few of them. Id. at 23. The Vietnamese government attributed partial responsibility for the violence to the international community for the mixed messages they sent regarding the ethnic Vietnamese. Id.

Cambodian authorities did not react energetically to attacks against ethnic Vietnamese. For example, during one incident, SOC police just 300 meters away did nothing to intervene. The provisional government waited five months before condemning the attack. This was unsurprising, as their rhetorie had manifested the same racial hatred that led to the attacks. Ultimately, only one arrest was made, and that was made by UNTAC, not the Cambodian police. In the meantime, government officials debated whether constitutional rights should be extended to the ethnic Vietnamese. As usual, this decision was put off indefinitely. 1993 HumaN RIGHTS REPORT, supra note 191 , at 603 .

384. Branigin, supra note 6 (citing a Vietnamese official from the Ministry of Labor).

385. Hepinstall, supra note 21 .

386. Id.

387. Makabenta, supra note 37. 
III

\section{Possible APPROACHES}

Mass deportation of the ethnic Vietnamese from Cambodia is not feasible without foreign assistance, which will not be forthcoming. However, this goal shapes current Cambodian immigration policy, infuses government rhetoric, and could lead to the breakdown of diplomacy between Vietnam and Cambodia. Therefore, it is crucial for the ethnic Vietnamese, and for the Cambodian nation as a whole, that Cambodia adopt a clear, non-discriminatory nationality law as soon as possible. The following Section discusses how Cambodia might achieve this goal while still addressing its present immigration concerns.

\section{A. Implementation: Closing Legislative and Policy Gaps}

Several steps are required in order to reduce discrimination and meet the perceived needs of Cambodian immigration and naturalization policy. First, the Cambodian National Assembly must pass a nondiscriminatory nationality law. Second, after such a law is adopted, Cambodia must adopt a sub-decree to determine which subgroups of the population qualify as aliens, and which subgroups qualify as nationals. Unfortunately, many people will not have convincing documentation to prove nationality due to the past twenty-five years of political instability. Given this unusual situation, the Cambodian National Assembly must adopt provisional measures to determine what kind of documentation is necessary and sufficient to establish a nationality claim. Finally, as most other nations allow for some method of naturalization, ${ }^{388}$ the Cambodian National Assembly should adopt a naturalization law under which immigrants can apply and qualify for nationality.

In order to avoid discrimination and to meet Cambodian immigration concerns simultaneously, such policies should meet several overlapping criteria. Any Cambodian policy should aim to minimize ad hoc as well as systematic discrimination. In addition, any Cambodian nationality law should eliminate discretion as much as possible. History has shown that officials abuse discretion by harassing and extorting the ethnic Vietnamese; a bright-line rnle would help reduce discrimination and corruption. Most importantly, any Cambodian nationality law should provide unambiguous definitions regarding who is a national and who is an alien.

Finally, under the International Covenant on Civil and Political Rights ("Covenant"), ${ }^{389}$ which Cambodia has ratified, any deportation policy should provide due process for individuals who allegedly arrived

388. The Movement of Persons Across Borders, supra note 17, at 42.

389. Supra note 293. 
illegally. A procedure that incorporates due process safeguards is essential for the protection of human rights and for the fulfillment of international standards.

Due process under the Covenant requires the Cambodian government to establish illegal entry before implementing deportation. Any policy that allows collective or mass expulsions would constitute a per se violation of the Covenant. Additionally, any presumption that all ethnic Vietnamese entered Cambodia illegally, or that all who "cannot speak Khmer" hold fraudulent documents, would violate due process. A presumption of illegal entry would be particularly egregious if existing documentation could never irrefutably prove many ethnic Vietnamese claims.

To comport with due process, the government should bear the burden of proof to establish that an individual entered Cambodia illegally. There are moral reasons why the government, rather than the ethnic Vietnamese, should carry this burden. People within Cambodia such as the ethnic Vietnamese have suffered enough due to governmental instability. They should not be forced to suffer again by forced deportation due to an effectively irrebuttable presumption of illegal entry. Nor should people who have made Cambodia their home be penalized because of a previous legal vacuum. Moreover, the government has already accepted moral leadership in Cambodia by claiming to honor human rights. The government should follow through on this leadership in implementing its immigration law.

The burden of proving illegal entry, initially difficult for the government to satisfy, will eventually become less onerous once the government has granted new papers to all Cambodian nationals. In the meantime, the Cambodian government could stem immigration by maintaining stricter border control. Otherwise, people will suspect that Vietnamese people continue to enter Cambodia illegally, which possibly could exacerbate animosity toward all ethnic Vietnamese in Cambodia.

\section{B. A Possible Model}

There are two general types of nationality laws. The first type, jus soli, grants nationality to those born within the territory. ${ }^{390}$ The second type, jus sanguinis, grants nationality based on blood ties; one would qualify for nationality based on descent, regardless of place of birth. ${ }^{31}$ Jus sanguinis thus allows a child born outside the nation to qualify for nationality based on the parents' nationality. ${ }^{392}$

390. Thomas A. Aleinikoff \& David A. Martin, Immigration: Process and Policy 944 (2d ed. 1991).

391. Id.

392. Id. at 947 . 
To consider more specifically what a Cambodian nationality law should include, it is useful to assess other nationality laws in the region. At the same time, one should note that due to colonialism and other historical and political concerns, each country's situation is unique. For example, Cambodia's immigration policy could be shaped by its historic border problems with Vietnam. On the other hand, protection of human rights should play a relatively large role in Cambodia because Cambodia has a history of egregious human rights abuses, and has signed a number of relevant international human rights conventions.

Nonetheless, the laws of Singapore, Thailand, the Philippines, and Malaysia provide useful examples of southeast Asian nationality laws. ${ }^{393}$ These countries combine aspects of jus sanguinis and jus soli by granting nationality to those who were born in the territory or who have fathers with the nationality of that territory. If Cambodia were to enact a similar law, it also would have to grant nationality to those with Cambodian mothers, because the Cambodian Constitution does not allow gender-based discrimination. ${ }^{394}$

Japan, on the other hand, has a nationality law based solely on jus sanguinis. ${ }^{395}$ As such, the law discriminates based on ethnicity: a lifelong resident of Korean ethnicity is not considered a Japanese national, but a Japanese-American could become a national upon moving to $\mathrm{Ja}$ pan. ${ }^{396}$ A similar law in Cambodia would perpetuate a political caste system, ensuring the vulnerability of certain ethnic groups. ${ }^{397}$ Cambodia can better protect ethnic minorities by avoiding the passsage of a comparable law.

Cambodian human rights groups have suggested a model that fundamentally complies with international law and the Cambodian Constitution. ${ }^{398}$ Under this model, anyone with identity papers establishing residency in Cambodia in 1975 (the beginning of the Khmer Rouge regime) or before would be considered a Cambodian national. In addition, anyone with papers establishing residency after 1979 would be considered a Cambodian national if he or she either has at least one Cambodian parent, or has married a Cambodian national and renounced Vietnamese citizenship. ${ }^{399}$

393. For a fuller discussion of these nationality laws, see generally Nationality AND International Law in Asian Perspective (Ko Swan Sik and Chang Hyo Sang eds., 1990).

394. See KINGDOM OF CAMBOdia Const., art. 36.

395. See Kiyoshi Hosokawa, Japanese Nationality in International Perspective, in Natronality and International LaW IN Asian Perspective, supra note 393, at 191.

396. See id. at I93.

397. See John C. Brown, Cambodia only for the Khmer?, PhNom PENh Post, June 3-I6, 1994.

398. Cambodian Human Rights Groups Urge Aid for Vietnamese, supra note 380.

399. This model should use the word "Khmer" for ethnicity and "Kampuchea" for Cambodian national in order to avoid ambiguity. See Ker Munthit, Nationality Law "Liberal" Though Some Cause for Concern, Phnom Penh Post, May 5-18, 1995 at 9. 
This model provides a starting point. However, it remains unclear who is considered a Cambodian national for the purposes of determining whether an individual has married one. This gap can be filled by adding a provision defining anyone born in Cambodia as a Cambodian national. This particularly will help anyone born after 1975. It will also help reduce statelessness by ensuring that every child born in Cambodia has a nationality, as required by the International Covenant on Civil and Political Rights. ${ }^{400}$

In addition, the law should incorporate a provision allowing for naturalization. Many countries require five to seven years for naturalization. ${ }^{401}$ In Cambodia, this would allow those who arrived pre-UNTAC to apply for nationality. With the addition of such a naturalization provision, many ethnic Vietnamese in Cambodia would be granted Cambodian nationality. Those currently entering illegally would not qualify.

Again, lack of documentation may preclude people from establishing when they arrived in Cambodia. It may be administratively easier for Cambodia to grant a period of amnesty for those people currently in Cambodia. This might result in the granting of nationality to more people than Cambodia really wants, or is required to accept under international principles. However, again, people who have made Cambodia their home should not be penalized because of a previously existing legal vacuum. A presumption that those who have established ties in Cambodia are lawfully within the territory and eligible for nationality would solve administrative problems, safeguard human rights, and reduce expenditures.

\section{CONCLUSION}

Cambodia seeks to enter a new era of democracy and freedom. In inaugurating this new era, the Accords stated that the primary objective of the reconstruction of Cambodia was the "advancement of the Cambodian nation and people, without discrimination or prejudice, and with full respect for human rights and fundamental freedom for all."402 In seeking to move forward, Cambodia must leave behind its legacy of genocidal massacres and crimes against humanity. To do so, the Cam-

400. See supra note 293, art. 24, 99 U.N.T.S. at 179.

401. See, e.g., Ko Swan Sik \& Teuku Moh Rhadie, Nationality and International Law in Indonesian Perspective, in Nationality and International LaW IN Asian Perspective, supra note 393, at 149; Sompong Sucharitkul, Thai Nationality in International Perspective, in NATIONALITY ANd International Law in Asian Perspective, supra note 393, at 472. But see Visu Sinnadurai, Nationality and Intemational Law in the Perspective of the Federation of Malaysia, in NATIONALITY ANd International LaW in Asian Perspective, supra note 393, at 324 (noting that Malaysia requires an aggregate of ten years for naturalization). Naturalization laws may also require good character and/or language requirements. Id. However, in Cambodia, these requirements would have to be explicitly defined to minimize abuse of discretion.

402. Accords, supra note 45, pt. IV, II 1,31 1.L.M. at 203. 
bodian government must itself take the moral high ground and refuse to pander to racist fear and historic animosity.

A non-discriminatory nationality law would be a large step in the right direction. Such a law would help ensure compliance with the Cambodian Constitution, the Paris Peace Accords, and the international human rights obligations that Cambodia has undertaken. Complying with these obligations would improve diplomatic relations with other nations, particularly Vietnam. Moreover, complying with its obligations would enable Cambodia to retain financial support from the international community and encourage foreign investment.

On the other hand, discriminating against one segment of the population will only perpetuate turmoil. For its own survival, the Cambodian government must show its willingness to adhere to the rule of law. The government cannot pay lip service to human rights yet continue to persecute ethnic minorities. Nor can the Cambodian government continue to disrespect human rights if it wants international support rather than condemnation.

The choices Cambodia now makes will determine its future. After years of suffering, the people of Cambodia, including the ethnic Vietnamese, deserve peace. The Cambodian government must support peace by putting past hostilities aside, and must support human rights by passing a non-discriminatory nationality law. 